\title{
Review
}

\section{Specificity in Legume-Rhizobia Symbioses}

\author{
Mitchell Andrews * and Morag E Andrews \\ Faculty of Agriculture and Life Sciences, Lincoln University, PO Box 84, Lincoln 7647, New Zealand; \\ moragandrews@gmail.com \\ * Correspondence: mitchell.andrews@lincoln.ac.nz; Tel.: +64-3-423-0692
}

\begin{abstract}
The Leguminosae (legume family) is divided into three sub-families, the Caesalpiniodeae, Mimosoideae and Papilionoideae. Here, the literature on legume-rhizobia symbioses was reviewed, and genotypically characterised rhizobia related to the taxonomy of the legumes they were isolated from. Only data from field soils were considered. The objective of the work was to assess to what extent legume specificity for rhizobial symbiont is related to legume taxonomy. Bradyrhizobium spp. were the exclusive rhizobial symbionts of species in the Caesalpinioideae but data are limited. Where tested, species within the two Mimosoideae tribes, Ingeae and Mimoseae were nodulated by different rhizobial genera. Generally, Papilionoideae species with indeterminate nodules were promiscuous in relation to rhizobial symbionts but high specificity for rhizobial partners appears to hold at tribe level for the Fabeae (Rhizobium spp.), genus level for Medicago (Ensifer spp.), Cytisus (Bradyrhizobium spp.) and Lupinus (Bradyrhizobium spp.), and species level for Galega spp. (Neorhizobium galegeae), Hedysarum coronarium (Rhizobium sullae), Cicer arietinum (Mesorhizobium spp.) and New Zealand native Sophora spp. (Mesorhizobium spp.). High legume specificity for rhizobial symbionts was linked to specific rhizobial symbiosis genes. For Papilionoideae species with determinate nodules, the Dalbergieae were primarily nodulated by Bradyrhizobium but were promiscuous with respect to Bradyrhizobium spp. while those in the Desmodieae, Phaseoleae, Psoraleae and Loteae were promiscuous across different rhizobial genera. Possible advantages and disadvantages of high specificity or promiscuity are discussed.
\end{abstract}

Keywords: Leguminosae; $\mathrm{N}_{2}$ fixation; nodulation

\section{Introduction}

The Leguminosae (= Fabaceae, the legume family) is comprised of ca 19,300 species within 750 genera which occur as herbs, shrubs, vines or trees in mainly terrestrial habitats and are components of most of the world's vegetation types [Lewis et al. 2005; Sprent 2009; LPWG 2013]. Currently, the legume family is divided into three sub-families, the Caesalpiniodeae, Mimosoideae and Papilionoideae [LPWG 2013, Cardoso et al. 2013]. Members of the Caesalpinioideae are grouped in four tribes, the Caesalpinieae, Cassieae, Cercideae and Detarieae comprising ca 170 genera and 2,250 species. The Mimosoideae are grouped in two tribes, the Ingeae and Mimoseae with ca 80 genera and 3,270 species while the Papilionoideae consists of 28 tribes with ca 480 genera and 13,800 species.

Most legume species can fix atmospheric nitrogen $\left(\mathrm{N}_{2}\right)$ via symbiotic bacteria (general term 'rhizobia') in root nodules and this can give them an advantage under low soil nitrogen $(\mathrm{N})$ conditions if other factors are favourable for growth [Raven 2010; Andrews et al. 2013]. Also, $\mathrm{N}_{2}$ fixation by legumes can be a major input of $\mathrm{N}$ into natural and agricultural ecosystems [Andrews et al. 2007, 2011; Jackson et al. 2008; Vitousek et al. 2013]. Generally, legume nodules can be classified as indeterminate or determinate in growth [Sprent 2009]. Indeterminate nodules maintain meristematic tissue while determinate nodules have a transient meristem. Nodule type is dependent on host plant, and legume species which can produce both determinate and indeterminate nodules are rare [Fernández-Lopez et al. 1998; Liu et al. 2014]. All genera examined 
in the Caesalpinioideae and Mimosoideae had indeterminate nodules (Sprent, 2009). Within the Papilionoideae, most tribes had indeterminate nodules but the Desmodieae, Phaseoleae, Psoraleae and some members of the Loteae show 'desmodoid' determinate nodules and the Dalbergieae 'aeschynomenoid' determinate nodules [Sprent 2009]. Most indeterminate nodules have a single persistent apical meristem, however, a few genera such as Lupinus (tribe Genisteae, Papilionoideae) and Listia (tribe Crotalaria, Papilionoideae), have nodules with two or more lateral meristems which in some cases completely surround the subtending root [Yates et al. 2007; Sprent 2009]. Rhizobia 'infected' tissue within desmodoid nodules always contains uninfected cells while aeschynomenoid nodules have uniform infected tissue and are always associated with lateral or adventitious roots (Sprent 2009).

Over the past twenty-five years, DNA based methods have become increasingly used to characterize rhizobia. In particular, phylogenetic analyses of sequences of the 16S ribosomal RNA (rRNA) gene, a range of 'housekeeping' genes and genes involved in symbiosis have been developed as a 'standard approach' [Martens et al. 2007; Liu et al. 2014; Peix et al. 2015]. The main symbiosis genes studied are the 'nif genes which encode the subunits of nitrogenase, the rhizobial enzyme that fixes $\mathrm{N}_{2}$, and the 'nod' genes which encode Nod factors that induce various symbiotic responses on legume roots. The nod genes are activated by plant root exudates mainly flavonoids [Masson-Boivin et al. 2009]. The 16S rRNA gene sequence on its own can delineate rhizobia at the genus level [Lindstrom et al. 2015]. The nif and nod genes are often carried on plasmids or symbiotic islands and these genes can be transferred (lateral transfer) between different bacterial species within a genus and more rarely across genera [Vinuesa et al. 2005b; Cummings et al. 2009; Remigi et al. 2016]. Bacterial species from a range of genera in the alphaproteobacteria (most commonly Bradyrhizobium, Ensifer (= Sinorhizobium), Mesorhizobium, and Rhizobium) and two genera in the betaproteobacteria (Burkholderia (= Paraburkholderia) and Cupriavidus) can form functional ( $\mathrm{N}_{2}$ fixing) nodules on specific legumes (Tables 1-4). Pseudomonas in the gammaproteobacteria was reported to nodulate Robinia pseudoacacia [Shiraishi et al. 2010] and Acacia confusa [Huang et al. 2012] but this has not been confirmed.

Legume species differ in their specificity for rhizobial symbionts. Galega officinalis (tribe Galegeae) and Hedysarum coronarium (tribe Hedysareae) have been highlighted as being highly specific with respect to their rhizobial symbionts [Lindström 1989; Squartini et al. 2002; Franche et al. 2009; Liu et al. 2012]. Both these species are in the inverted repeat lacking clade (IRLC). The IRLC is marked by the loss of one copy of the inverted region of the plastid genome (Wojciechowski et al. 2004; Schwarz et al. 2015]. Almost all genera in the IRLS are temperate and all have indeterminate nodules. The IRLC contains several important temperate grain (e.g. Pisum sativum and Vicia faba) and forage (e.g. Trifolium spp. and Medicago spp.) legumes. There is evidence that at least some of these crop legumes have a high degree of rhizobial specificity. For example, an analysis of core and symbiotic genes of rhizobia nodulating Vicia faba and Vicia sativa from different continents showed that they belong to a phylogenetically compact group indicating that these species are restrictive hosts [Álvarez-Martinez et al. 2009]. In contrast, Macroptilium purpureum and the grain legumes Phaseolus vulgaris and Vigna unguiculata in the tribe Phaseoleae are nodulated by rhizobia from different genera across the alpha- and beta-proteobacteria [Martínez-Romero 2003; Elliot et al. 2007; Guimarães et al. 2012; Table 4]. The Phaseoleae are of tropical/subtropical origin and have determinate (desmodoid) nodules [Sprent 2009].

Here, the literature on legume-rhizobial symbioses was reviewed, and genotypically-characterised rhizobia related to the taxonomy of the legumes they were isolated from. Only data from field soils were considered. The objective of the work was to assess to what extent legume specificity for rhizobial symbiont is related to legume taxonomy.

\section{Framework and assumptions of study}

The general classification of the Leguminosae follows Lewis et al. 2005 [Lewis et al. 2005] with updates [LPWG 2013; Cardoso et al. 2013]. The sub-families Caesalpiniodeae, Mimosoideae and Papilionoideae are considered separately. The Papilionoideae is split into those that show 
indeterminate nodules and those that show determinate nodules. Those that show indeterminate nodules are further split into the IRLC, and all other clades.

Nodulating bacteria were classified to genus level, on the basis of sequences of the 16S rRNA gene (almost all cases), and/ or the 16S-23S DNA intergenic spacer region, and/ or common house-keeping genes, and/ or DNA-DNA hybridisations and these results are presented in tables. Cases where legume specificity for rhizobial symbiont appeared to occur at genus level are considered further in the text. Rhizobial genus and species names validated in the International Journal of Systematic and Evolutionary Microbiology were used with one exception; Burkholderia was retained as opposed to using Paraburkholderia [Oren \& Garrity 2015; Dobritsa \& Samadpour 2016] as a case to reinstate Burkholderia is being prepared by workers in the field. The term symbiovar (sv.) is used when describing rhizobial strains within the same species which differ with respect to the legume species they effectively nodulate [Rogel et al. 2011].

A comprehensive collation of published legume-rhizobia symbioses was carried out. Articles were collected by searching the ISI Web of Science using each legume genus partnered with each of rhizobia, Bradyrhizobium, Burkholderia, Cupriavidus, Ensifer, Mesorhizobium, Rhizobium and Sinorhizobium as key words. Further searches were carried out on the literature quoted in the selected papers and those listed as quoting the selected papers in ISI Web of Science. Only data for plants sampled under field conditions, or for plants grown in soils taken from the field, or supplied field soil extracts, were used. Bacteria isolated from legume nodules were accepted as rhizobia if they were shown to produce functional ( $\mathrm{N}_{2}$ fixing) nodules on inoculation of their original legume host or a species within the original host legume genus under axenic conditions. The range of measurements and visual assessments used as evidence of the occurrence of $\mathrm{N}_{2}$ fixation were accepted. These were acetylene reduction activity, red/pink nodules (evidence of haemoglobin and hence nodules assumed to be active), increased total plant or shoot dry matter or $\mathrm{N}$ content, visually greener (increased chlorophyll) and increased plant vigour. However, it is acknowledged that in some cases, greater growth, vigour and/ or greenness could have been caused by plant hormone production by the bacterium [Andrews et al. 2003]. All data obtained for all species are presented with three exceptions. Representative data are presented for Glycine max, Phaseolus vulgaris and Vigna unguiculata due to the large number of publications on these three species.

\section{Caesalpinioideae-Rhizobia Symbioses}

Of the three legume sub-families, the Caesalpinioideae contains the smallest proportion of nodulated genera with nodulation confirmed for Campsiandra, Chidlowia, Dimorphandra, Erythrophleum, Melanoxylon, Moldenhauwera and Tachigali in the tribe Caesalpinieae and Chamaecrista in the tribe Cassieae [Sprent 2009]. Only two studies have genotypically characterised rhizobia of Caesalpinioideae species. Firstly, five rhizobial isolates from Dimorphandra wilsonii and one from Dimorphandra jorga sampled in the Cerrado biome in Brazil were Bradyrhizobium [Fonseca et al. 2012]. Secondly, 166 rhizobial isolates from Erythrophleum fordii sampled at four sites in the Guangdong and Guangsii Provinces of the southern sub-tropical region of China were also all Bradyrhizobium [Yao et al. 2014]. In both studies, core and symbiosis gene sequences indicated that there were diverse and novel strains amongst the isolates.

Data are available for bacterial isolates from nodules of other Caesalpinioideae species but their ability to produce $\mathrm{N}_{2}$ fixing nodules on their legume host under axenic conditions was not tested. Specifically, three isolates from Tachigali versicolor sampled on Barro Colorado Island, Panama which were not tested on their original host plant but shown to nodulate Macroptilium atropurpureum were Bradyrhizobium [Parker 2000]. Similarly, strain STM934, stated to be confirmed as Bradyrhizobium was isolated from nodules of Erythrophleum guineensis growing in natural forests of the Ziama reservation in S.E. Guinea and shown to produce functional nodules on Macroptilium atropurpureum [Diabate et al. 2005]. In this case, a re-inoculation experiment was carried out on the original host but the substrate was non-sterile forest soil. Bradyrhizobium was isolated from and shown to nodulate Chamaecrista sampled in Kakadu National Park, Northern Territory, Australia but $\mathrm{N}_{2}$ fixation was not reported [Lafay \& Burdon 2007]. Also, there are several reports that 
Bradyrhizobium inoculum can increase nodulation of Chamaecrista spp. under field conditions in Australia and China [Michalk and Zhi-Kai 1994; Keller 2014; www.tropicalforagesinfo]. Thus, overall, the available evidence indicates that Bradyrhizobium spp. are the dominant, possibly exclusive, rhizobial symbionts of legumes in the Caesalpinioideae but the degree of specificity between legumes in the Caesalpinioideae and their rhizobial symbionts cannot be assessed without further work.

\section{Mimosoideae-Rhizobia Symbioses}

Rhizobia have been characterized from 15 species across seven genera in the tribe Ingeae and ca 90 species from 13 genera in the tribe Mimoseae within the sub-family Mimosoideae (Table 1). Bradyrhizobium, Ensifer, Mesorhizobium and Rhizobium were each reported to nodulate species in the Ingeae and the Mimoseae. Also, Ochrobactrum was reported to nodulate Acacia mangium (Ingeae), Allorhizobium and Devosia were reported to nodulate Neptunia natans (Mimoseae), and there are many reports that Cupriavidus and Burkholderia nodulate Mimosa spp. and related species (Mimoseae) (Table 1). In addition, with the exception of Acacia auriculiformis (Ingeae) and Mimosa diplotricha (Mimoseae), all species which were examined in three or more separate studies, Acacia mangium, Acacia saligna, Calliandra grandiflora and Senegalia senegal (Ingeae), Leucaena leucocephala, Mimosa pudica, Parapiptadenia rigida, Prosopis alba and Vachellia tortilis (Mimoseae), were nodulated by at least three different rhizobial genera. Thus, a range of rhizobial genera, including both alphaand beta-proteobacteria, can nodulate legume species across the two Mimosoideae tribes and, generally, where tested over different studies, species within the Ingeae and Mimoseae tribes were promiscuous with respect to their rhizobial symbionts.

Despite their ability to form symbioses with different rhizobial genera, Mimosa spp. appear to be predominantly nodulated by Burkholderia in Brazil, Ensifer/Rhizobium in Mexico and Cupriavidus in Uruguay [Bontemps et al. 2010, 2016, dos Reis et al. 2010, Platero et al. 2016]. This is likely to be at least in part related to the relative occurrence of the potential symbionts in the different soils due, for example, to differences in soil pH [Bontemps et al 2016, Platero et al 2006]. However, it has been reported that in competition studies between a Burkholderia strain, a Cupriavidus strain and three Rhizobium strains which were all potential rhizobial symbionts of three Mimosa spp., the Burkholderia strain outcompeted the other strains to the point of exclusion in flooded soils [Elliott et al. 2009]. This advantage of the Burkholderia strain could not be explained by differences in initial inoculum levels, growth rate, growth inhibition of the other rhizobia or nodulation rate but the advantage decreased if $0.5 \mathrm{mM}$ nitrate was added to the system. These data show that the competitive ability of different potential rhizobial strains can be greatly dependent on environmental conditions.

\section{Papilionoideae-Rhizobia Symbioses}

\subsection{The IRLC}

Data are available for 110 species from 29 genera within six tribes in the IRLC with Ensifer, Mesorhizobium, and Rhizobium commonly, and Bradyrhizobium, Neorhizobium and Phyllobacterium rarely, reported to nodulate species within this clade (Table 2). There are no reports of Burkholderia or Cupriavidus symbionts within the IRLC. Previously, Galega officinalis, Galega orientalis and Hedysarum coronarium were reported to only form effective nodules with their respective symbionts Neorhizobium galegeae sv. officinalis, Neorhizobium galegeae sv. orientalis and Rhizobium sullae [Lindström 1989; Squartini et al. 2002; Franche et al. 2009; Liu et al. 2012]. Several mechanisms maintain these highly specific legume-rhizobia symbioses [Suominen et al. 2003; Franche et al 2009; Gharzouli et al. 2013]. For example, in the Galega orientalis - Neorhizobium galegeae sv. orientalis interaction, the first recognition between the flavonoid inducer secreted from the roots of Galega orientalis and the NodD protein of $N$. galegeae sv. orientalis is specific for these organisms [Suominen et al 2003].

The data in Table 2, indicate three other specific relationships between IRLC legumes and rhizobia. Firstly, eight separate studies on Cicer arietinum carried out over different countries and 
continents, reported Mesorhizobium as the only symbiont (Table 2). Mesorhizobium ciceri and $M$. mediterraneum were common but not exclusive Mesorhizobium symbionts of Cicer arietinum in most studies outside China with M. muleiense the main symbiont in Northwest China [Zhang et al 2016]. In the three studies where tested, Mesorhizobium symbionts other than M. ciceri, M. mediterraneum and $M$. muleiense showed nifH and nodC gene sequences similar to these three common symbionts indicating that Cicer arietinum strongly selects rhizobia with specific symbiotic genes [Rivas et al 2006; Zhang et al 2012, 2016].

Secondly, for the tribe Fabeae, seventeen studies across five Lathyrus species, Lens culinaris, Pisum sativum and eleven Vicia spp. reported Rhizobium as the only symbiont. Across these studies, Rhizobium leguminosarum and where tested, R. leguminosarum sv. viciae was the most common symbiont. Also, in a study of 154 isolates of 18 Vicia species grown in 16 Chinese provinces, only 17 representative Rhizobium leguminosarum sv. viciae isolates, from a wide range of potential rhizobia, produced fully developed, effective ('color red') nodules [Lei et al. 2008]. Thus, a highly specific relationship has developed between species in the Fabeae and R. leguminosarum sv. viciae but it is not an exclusive relationship as R. fabeae [Tian et al 2008], R. multihospitium [Han et al 2008b], R. pisi [Santillana et al 2008], R. laguerreae [Said et al 2014] and R. anhuiense [Zhang et al 2015] have been reported to effectively nodulate Fabeae species. However, the nifH and nodC gene sequences of all these rhizobia show high similarity indicating specificity towards the Fabeae species [Zhang et al. 2015].

Thirdly, within the tribe Trifolieae, 12 out of 13 separate studies across 11 Medicago spp. reported Ensifer as symbiont although in some cases not exclusively. In particular, highly specific relationships have developed between Medicago spp. and the closely related (core and symbiosis genes) E. meliloti and E. medicae with symbiovars of these rhizobial species associated with particular Medicago spp. (Villegas et al. 2006; Gubry Rangin et al. 2013).

In relation to other members of the IRLC, Ensifer, Mesorhizobium and Rhizobium were shown to nodulate species within Astragalus, Colutea, Glycyrrhiza, Oxytropis and Sphaerophyceae (Galegeae), Caragana (Hedysareae), Tephrosa (Millettieae) and Trifolium (Trifolieae). Also, Astragalus adsurgense, Astragalus complanatus, Colutea arborescens, Oxytropis glabera and Sphaerophysia sabula (Galegeae), Caragana intermedia (Hedysareae), Tephrosia purpurea (Millettieae) and Trifolium fragiferum and Trifolium repens (Trifolieae) were all nodulated by three different rhizobial genera. Thus, for the IRLC, high specificity in relation to rhizobial partners appears to hold at tribe level for the Fabeae, genus level for Medicago and species level for Galega officinalis, Galega orientalis, Hedysarum coronarium and Cicer arietinum but it is not a characteristic of all members of the clade.

\subsection{Clades with indeterminate nodules, excluding the IRLC}

Data are available for approximately 100 species from 50 genera across 11 Papilionoideae tribes with indeterminate nodules which do not show the IRLC mutation (Table 3). Azorhizobium, Bradyrhizobium, Burkholderia, Ensifer, Herbaspirillum, Mesorhizobium, Methylobacterium, Microvirga, Neorhizobium, Ochrobactrum, Pararhizobium, Phyllobacterium and Rhizobium were all reported to nodulate species within this group. Amorpha fructicosa and Dalea purpurea (Amorpheae), Retama sphaerocarpa and Spartium junceum (Genisteae), Coronilla varia (Loteae), Gliricidia sepium and Robinia pseudoacacia (Robineae) and Sesbania sericea and Sesbania virgata (Sesbanieae) were nodulated by two rhizobial genera. Aspalathus linearis and Crotalaria pallida (Crotalarieae), Sesbania cannabina, Sesbania punicea, Sesbania rostrata and Sesbania sesban (Sesbanieae), Sophora alopecuroides and Sophora flavescens (Sophoreae) and Ammopiptanthus nanus and Ammopiptanthus mongolicus (Thermopsideae) were all nodulated by at least three different rhizobial genera. Thus, generally, where tested, Papilionoideae species with indeterminate nodules excluding the IRLC were promiscuous in relation to rhizobial symbiont. However, within the Genisteae, Bradyrhizobium was the only symbiont reported for nine Cytisus spp. across ten separate studies and three Genista spp. across three separate studies (Table 3). Also, 10 Lupinus spp. (Genisteae) across 11 separate studies were predominantly nodulated by Bradyrhizobium. These results indicate that Bradyrhizobium may be the main symbionts of Genisteae species but further work is required to confirm this. The relationship 
between Cytisus spp. and Lupinus spp. and their Bradyrhizobium symbionts is highly specific and dependent on geographical origin of the legumes. For example, most Bradyrhizobium isolates from Lupinus spp. in Europe form a distinct lineage, 'clade 11', on the basis of their nodC gene sequences [Stepkowski et al. 2007, 2011]. Similarly, different Bradyrhizobium spp. associated with Cytisus villosus in Morocco all showed similar nodC and nifH sequences which were closely related to those of Bradyrhizobium japonicum sv. genistearum [Chahboune et al. 2011].

On more limited data (one study), Bradyrhizobium was found to be the exclusive symbiont of four Indigofera spp. [Doignon-Bourcier et al. 1999] although in a separate study Burkholderia was reported to be the symbiont of Indigofera angustifolia [Lemaire et al. 2015]. Also, in one study, in the Cape Floristic Region (CFR) of South Africa, Burkholderia was reported to be the exclusive symbiont of ten Cyclopia spp., Podalyria calyptera and Virgilia oroboides, all species in the Podalyrieae plus three Hypocalyptus spp. (Hypocalypteae) [Beukes et al. 2013]. Burkholderia was confirmed to nodulate Podolyria calyptrata and Virgilia oroboides in the CFR [Lemaire et al. 2015]. The majority of Burkholderia isolates had unique nifH and nodA gene sequences and the specificity of these symbioses needs testing.

Previously, Sesbania sesban was reported to be highly promiscuous with respect to rhizobial symbionts [Cummings et al. 2009] and the data here indicate that this could be a genus level trait (Table 3). However, the reports that Sophora alopecuroides and Sophora flavescens sampled in China are nodulated by a wide range of rhizobial genera with a wide range of symbiosis gene sequences [Zhao et al. 2010; Jiao et al. 2015a] contrasts with the finding that New Zealand (NZ) native Sophora spp. were exclusively nodulated by Mesorhizobium spp. with almost identical unique nodA and nodC gene sequences [Tan et al. 2015; De Meyer et al. 2015, 2016]. Also, none of twenty rhizobial isolates from common weed and crop legumes in NZ produced functional nodules on the NZ native Sophora microphylla [Liu 2014]. This emphasises that species within the same genus can vary greatly with respect to their specificity for rhizobial symbionts.

\subsection{Clades with Determinate Nodules}

The Dalbergieae are almost exclusively of tropical/ sub-tropical distribution and show aeschynomenoid determinate nodule structure (Sprent 2009). Rhizobia have been characterised for 24 species from seven genera in the Dalbergieae, Adesmia, Aeschynomene, Arachis, Centrolobium, Dalbergia, Pterocarpus and Zornia (Table 4). Bradyrhizobium was found to nodulate all species except Adesmia bicolor (Rhizobium) and Dalbergia odorifera (Burkholderia), with Rhizobium also reported for Arachis hypogaea. For Arachis hypogaea, twelve separate studies reported Bradyrhizobium as a rhizobial symbiont with two of these also reporting Rhizobium. Thus, on the data available, Arachis hypogaea and the Dalbergieae, in general, appear to be primarily nodulated by Bradyrhizobium. However, across studies, both core and symbiosis gene sequences indicate that Arachis hypogaea, Arachis duranensis and Aeschynomene spp. are nodulated by a diverse range of Bradyrhizobium spp. and are promiscuous with respect to Bradyrhizobium spp.

The closely related tribes Desmodieae, Phaseoleae and Psoraleae are also mainly of tropical/ sub-tropical distribution and, with rare exceptions, species within these tribes showed desmodoid nodule structure (Sprent 2009; Liu et al. 2014). Rhizobia have been characterized for 25 species from three genera, Desmodium, Kummerowia and Laspedeza, in the Desmodieae (Table 4). Species from all three genera, Desmodium microphyllum, Desmodium racemosum, Desmodium sequax, Kummerowia striata, Lespedeza bicolor and Lespedeza daurica were nodulated by rhizobia from three separate genera. Similarly, for 28 species across 14 genera within the Phaseoleae, there was no strong evidence for high specificity for rhizobial symbiont (Table 4). Phaseolus vulgaris and Vigna unguiculata have been highlighted as being promiscuous with respect to their rhizobial symbionts under field conditions. Data in Table 4 show that both species can be nodulated by different rhizobial genera in the alphaproteobacteria as well as Burkholderia in the betaproteobacteria. Across three studies, Phaseolus lunatus was reported to be nodulated by Bradyrhizobium and Rhizobium while on one study each, both Vigna sangularis and Vigna subterranean were reported to be nodulated by three separate rhizobial genera. Data are limited for other genera/ species within the Phaseoleae with the 
exception of Glycine max which is the main grain/ oil seed legume grown worldwide. Glycine max was nodulated by Bradyrhizobium, Ensifer and Rhizobium. Data are limited for Psoraleae but in the one case where two separate studies were carried out on the one species (Psoralea pinnata) it was nodulated by Burkholderia and Mesorhizobium [Kanu \& Dakora 2012; Lemaire et al. 2015]. Thus, where tested, species within the Desmodieae, Phaseoleae and Psoraleae were promiscuous with respect to their rhizobial symbionts.

Species in the Loteae which show desmodoid nodule structure are of temperate distribution [Sprent 2009]. Data are available for 16 Lotus spp. within the Loteae across 13 separate studies.. For all species examined in two or more studies at least two rhizobia genera were reported as symbionts. In the case of Lotus corniculatus, Geobacillus, Paenibacillus and Rhodococcus were for the first time reported as rhizobial symbionts (Ampomah and Huss-Danell 2011). These bacterial species had similar symbiosis gene sequences to Mesorhizobium isolated from the same plants and it was concluded that lateral gene transfer of these genes had occurred from the Mesorhizobium. However, this work needs to be independently verified. Overall, the available data indicate that legume species with desmodoid determinate nodule structure are promiscuous with respect to their rhizobia symbionts.

\section{Legume Specificity for Rhizobial Symbionts}

High specificity or promiscuity of legumes with respect to rhizobial symbionts are both likely to have advantages and disadvantages to the legume [Ehinger et al. 2014]. For example, promiscuity could allow a legume to participate in a wider range of beneficial interactions and hence possibly occupy more environments. However, high specificity is likely to result in increased 'fitness', e.g. increased $\mathrm{N}_{2}$ fixation, within a narrower range of conditions [Ehinger et al 2014]. In an agricultural situation, the degree of crop legume specificity for rhizobial symbiont is an important factor in determining the level of success of applied rhizobial inoculant [Andrews et al. 2009].

The objective of the work was to assess to what extent legume specificity for rhizobial symbiont is related to legume taxonomy. The legume sub-families, Caesalpiniodeae, Mimosoideae and Papilionoideae were considered separately with species in the Papilionoideae split in relation to whether they show indeterminate or determinate nodules. Bradyrhizobium spp. were the exclusive rhizobial symbionts of species in the Caesalpinioideae but rhizobia were authenticated for only three legume species over two studies and the degree of specificity between legumes in the Caesalpinioideae and their rhizobial symbionts cannot be assessed without further work.

In relation to the Mimosoideae, generally, where examined in three or more studies, species within both the Ingeae and Mimoseae tribes were promiscuous with respect to their rhizobial symbionts and there is no strong evidence for high specificity for rhizobial symbionts for any species in this sub-family. For Papilionoideae species with determinate nodules, the Dalbergieae were primarily nodulated by Bradyrhizobium but were promiscuous with respect to Bradyrhizobium spp. while those in the Desmodieae, Phaseoleae, Psoraleae and Loteae were promiscuous across different rhizobial genera. Papilionoideae species with indeterminate nodules were split into the IRLC, and all other clades. A range of species within both groups nodulated with different rhizobia genera but there was also strong evidence that some species within both groups showed high specificity for rhizobial symbiont. High specificity for rhizobial symbiont appears to hold at tribe level for the Fabeae (Rhizobium spp.), genus level for Medicago (Ensifer spp.), Cytisus (Bradyrhizobium spp.) and Lupinus (Bradyrhizobium spp.), and species level for Galega spp. (Neorhizobium galegeae), Hedysarum coronarium (Rhizobium sullae), Cicer arietinum (Mesorhizobium spp.) and NZ native Sophora spp. (Mesorhizobium spp.). In all cases, this high specificity involved rhizobial species within the alphaproteobacteria and was associated with specific symbiosis genes of the rhizobial symbiont (Sections 5.1, 5.2). The legume species which show high specificity in rhizobial symbionts have common features in that they are all within the Papilionoideae, have indeterminate nodules and are of temperate distribution. 


\section{References}

1. Alam, F.; Bhuiyan, M.A.H.; Alam, S.S.; Waghmode, T.R.; Kim, P.J. Effect of Rhizobium sp. BARIRGm901 inoculation on nodulation, nitrogen fization and yield of soybean (Glycine max) genotypes in gray terrace soil. Biosci. Biotechnol. Biochem. 2015, 1660-1668.

2. Alvarez-Martínez, E.R.; Valverde, Á.; Ramírez-Bahena, M.H.; García-Fraile, P.; Tejedor, C.; Mateos, P.F.; Santillana, N.; Zúñiga, D.; Peix, A.; Velázquez, E. The analysis of core and symbiotic genes of rhizobia nodulating Vicia from different continents reveals their common phylogenetic origin and suggests the distribution of Rhizobium leguminosarium strains together with Vicia seeds. Arch. Microbiol. 2009, 191, 659-668.

3. Amarger, N.; Macheret, V.; Laguerre, G. Rhizobium gallicum sp. nov. and Rhizobium giardinii sp. nov., from Phaseolus vulgaris nodules. Int. J. Syst. Bacteriol. 1997, 47, 996-1006.

4. Ampomah, O.Y.; Huss-Danell, K. Genetic diversity of root nodule bacteria nodulating Lotus corniculatus and Anthyllis vulneraria in Sweden. Syst. Appl. Microbiol. 2011, 34, 267-275.

5. Ampomah, O.Y.; Huss-Danell, K. Nodulation of Thermopsis lupinoides by a Mesorhizobium huakuii strain with a unique nodA gene in Kamtchatka, Russia. Appl. Environ. Microbiol. 2011, 77, 5513-5516.

6. Ampomah, O.Y.; Huss-Danell, K. Genetic diversity of rhizobia nodulating native Vicia spp. in Sweden. Syst. Appl. Microbiol. 2016, 39, 203-210.

7. Andam, C.P.; Mondo, S.J.; Parker, M.A. Monophyly of nodA and nifH genes across Texan and Costa Rican populations of Cupriavidus nodule symbionts. Appl. Env. Microbiol. 2007, 73, 4686-4690.

8. Andrews, M.; James, E.K.; Cummings, S.P.; Zavalin, A.A.; Vinogradova, L.V.; McKenzie, B.A. Use of nitrogen fixing bacteria inoculants as a substitute for nitrogen fertiliser for dryland graminaceous crops: progress made, mechanisms of action and future potential. Symbiosis, 2003, 35, 209-229.

9. Andrews, M.; James, E.K.; Sprent, J.I.; Boddey, R.M.; Gross, E.; dos Reis Jr, F.B. Nitrogen fixation in legumes and actinorhizal plants in natural ecosystems: values obtained using ${ }^{15} \mathrm{~N}$ natural abundance. Plant Ecol. Divers. 2011, 4, 131-140.

10. Andrews, M.; Lea, P.L.; Raven, J.A.; Azevedo, R.A. Nitrogen use efficiency. 3. Nitrogen fixation: genes and costs. Ann. Appl. Biol. 2009, 155, 1-13.

11. Andrews, M.; Raven, J.A.; Lea, P.J. Do plants need nitrate? The mechanisms by which nitrogen form affects plants. Ann. Appl. Biol. 2013, 163, 174-199.

12. Andrews, M.; Scholefield, D.; Abberton, M.T.; McKenzie, B.A.; Hodge, S.; Raven, J.A. Use of white clover as an alternative to nitrogen fertilizer for dairy pastures in nitrate vulnerable zones in the UK: productivity, environmental impact and economic considerations. Ann. Appl. Biol. 2007, 151, 11-23.

13. Aoki, S.; Kondo, T.; Prévost, D.; Nakata, S.; Kajita, T.; Itó, M. Genotypic and phenotypic diversity of rhizobia isolated from Lathyrus japonicus indigenous to Japan. Syst. Appl. Microbiol. 2010, 33, 383-397.

14. Aouani, M.E.; Mhamdi, R.; Jebara, M.; Amarger, N. Characterization of rhizobia nodulating chickpea in Tunisia. Agronomie 2001, 21, 577-581.

15. Appunu, C.; Sasirekha, N.; Prabavathy, V.R.; Nair, S. A significant proportion of indigenous rhizobia from India associated with soybean (Glycine max L.) distinctly belong to Bradyrhizobium and Ensifer genera. Biol. Fertil. Soils 2009, 46, 57-63.

16. Araujo, J.; Díaz-Alcántara, C-A.; Velázquez, E.; Urbano, B.; González-Andrés, F. Bradyrhizobium yuanmingense related strains form nitrogen-fixing symbiosis with Cajanus cajan L. in Dominican Republic and are efficient biofertilizers to replace N fertilization. Sci. Hort. 2015, 192, 421-428.

17. Ardley, J.K.; Parker, M.A.; De Meyer, S.E.; Trengove, R.D.; O'Hara, G.W.; Reeve, W.G.; Yates, R.J.; Dilworth, M.J.; Willems, A.; Howieson, J.G. Microvirga lupini sp. nov., Microvirga lotononidis sp. nov. and Microvirga zambiensis sp. nov. are alphaproteobacterial root-nodule bacteria that specifically nodulate and fix nitrogen with geographically and taxonomically separate legume hosts. Int. J. Syst. Evol. Microbiol. 2012, 62, 2579-2588.

18. Armas-Carpote, N.; Pérez-Yépez, J.; Martínez-Hidalgo, P.; Garzón-Machado, V.; del Arco-Aguilar, M.; Velázquez, E.; Léon-Barrios, M. Core and symbiotic genes reveal nine Mesorhizobium genospecies and three symbiotic lineages among the rhizobia nodulating Cicer canariense in its natural habitat (La Palma, Canary Islands). Syst. Appl. Microbiol. 2014, 37, 140-148. 
19. Ba, S.; Willems, A.; de Lajudie, P.; Roche, P.; Jeder, H.; Quatrini, P.; Neyra, M.; Ferro, M.; Promé J-C.; Gillis, M.; Boivin-Masson, C.; Lorquin, J. Symbiotic and taxonomic diversity of rhizobia isolated from Acacia tortilis sp. subsp. Raddiana in Africa. Syst. Appl. Microbiol. 2002, 25, 130-145.

20. Badri, Y.; Zribi, K.; Badri, M.; Huguet, T.; van Berkum, P.; Aouani, M.E. Comparison of rhizobia that nodulate Medicago laciniata and Medicago truncatula present in a single Tunisian arid soil. Canadian J. Microbiol. 2007, 53, 277-283.

21. Baimiev, Al.Kh.; Baimiev, An.Kh.; Gubaidullin, I.I.; Kulikova, O.L.; Chemeris, A.V. Bacteria closely related to Phyllobacterium trifolii according to their 16S rRNA gene are discovered in the nodules of Hungarian sainfoin. Genetika, 2007, 43, 587-590.

22. Bala, A.; Giller, K.E. Symbiotic specificity of tropical tree rhizobia for host legumes. New Phytol. 2001, 149, 495-507.

23. Baraúna, A.C.; da Silva, K.; Pereira, G.M.D.; Kaminski, P.E.; Perin, L.; Zilli, J.E. Diversity and nitrogen fixation efficiency of rhizobia isolated from nodules of Centrolobium paraense. Pesquisa. Agropecu. Bras. 2014, 49, 296-305.

24. Barcellos, F.G.; Menna, P.; Batista, J.S.da S.; Hungria, M. Evidence of horizontal transfer of symbiotic genes from a Bradyrhizobium japonicum inoculant strain to indigenous diazotrophs Sinorhizobium (Ensifer) fredii and Bradyrhizobium elkanii in a Brazilian savannah soil. Appl. Environ. Microbiol. 2007, 73, 2635-2643.

25. Barrett, C.F.; Parker, M.A. Prevalence of Burkholderia sp. nodule symbionts on four mimosoid legumes from Barro Colorado Island, Panama. Syst. Appl. Microbiol. 2005, 28, 57-65.

26. Barrett, C.F.; Parker, M.A. Coexistence of Burkholderia, Cupriavidus, and Rhizobium sp. nodule bacteria on two Mimosa spp. in Costa Rica. Appl. Environ. Microbiol. 2006, 72, 1198-1206.

27. Bejarano, A.; Ramírez-Bahena, M-H.; Velázquez, E.; Peix, A. Vigna unguiculata is nodulated in Spain by endosymbionts of Genisteae legumes and by a new symbiovar (vignae) of the genus Bradyrhizobium. Syst. Appl. Microbiol. 2014, 37, 533-540.

28. Ben Romdhane, S.; Trabelsi, M.; Aouani, M.E.; de Lajudie, P.; Mhamdi, R. The diversity of rhizobia nodulating chickpea (Cicer arietinum) under water deficiency as a source of more efficient inoculants. Soil Biol. Biochem. 2009, 41, 2568-2572.

29. Benata, H.; Mohammed, O.; Noureddine, B.; Abdelbasset, B.; Abdelmoumen, H.; Muresu, R.; Squartini, A.; El Idrissi, M.M. Diversity of bacteria that nodulate Prosopis juliflora in the eastern area of Morocco. Syst. Appl. Microbiol. 2008, 31, 378-386.

30. Beukes, C.W.; Stępkowski, T.; Venter, S.N.; Cłapa T.; Phalane, F.L.; le Roux, M.M.; Steenkamp, E.T. Crotalaria and Genisteae of the South African Great Escarpment are nodulated by novel Bradyrhizobium species with unique and diverse symbiotic loci. Mol. Phylogenet. Evol. 2016, 206-218.

31. Beukes, C.W.; Venter, S.N.; Law, I.J.; Phalane, F.L.; Steenkamp, E.T. South African papilionoid legumes are nodulated by diverse Burkholderia with unique nodulation and nitrogen-fixation loci. PLoS ONE 2013, 8 (7), e68406.

32. Beyhaut, E.; Tlusty, B.; van Berkum, P.; Graham, P.H. Rhizobium giardinii is the microsymbiont of Illinois bundleflower (Desmanthus illinoensis (Michx.) Mcmillan) in Midwestern prairies. Can. J. Microbiol. 2006, 52, 903-907.

33. Bianco, L.; Angelini, J.; Fabra, A.; Malpassi, R. Diversity and symbiotic effectiveness of indigenous rhizobia-nodulating Adesmia bicolor in soils of Central Argentina. Curr. Microbiol. 2013, 66, 174-184.

34. Blanco, A.R.; Csukasi, F.; Abreu, C.; Sicardi, M. Characterization of rhizobia from Sesbania species native to seasonally wetland areas in Uruguay. Biol. Fertil. Soils 2008, 44, 925-932.

35. Bontemps, C.; Elliott, G.N.; Simon, M.F.; dos Reis Jr, F.B.; Gross, E.; Lawton, R.C.; Neto, N.E.; Loureiro, M.deF.; de Faria, S.M.; Sprent, J.I.; James, E.K.; Young, P.W. Burkholderia species are ancient symbionts of legumes. Mol. Ecol. 2010, 19, 44-52.

36. Bontemps, C.; Rogel, M.A.; Wiechmann, A.; Mussabekova, A.; Moody, S.; Simon, M.F.; Moulin, L.; Elliott, G.N.; Lacercat-Didier, L.; Dasilva, C.; Grether, R.; Camargo-Ricalde, S.L.; Chen, W.; Sprent, J.I.; Martínez-Romero, E.; Young, J.P.W.; James, E.K. Endemic Mimosa species from Mexico prefer alphaproteobacterial rhizobial symbionts. New Phytol. 2016, 209, 319-333.

37. Bourebaba, Y.; Durán, D.; Boulila, F.; Ahnia, H.; Boulila, A.; Temprano, F.; Palacios, J.M.; Imperial, J.; Ruiz-Argüeso, T.; Rey, L. Diversity of Bradyrhizobium strains nodulating Lupinus micranthus on both sides of the Western Mediterranean: Algeria and Spain. Syst. Appl. Microbiol. 39, 266-274. 
38. Bournaud, C.; de Faria, S.M.; dos Santos, J.M.F.; Tisseyre, P.; Silva, M.; Chaintreuil, C.; Gross, E.; James, E.K.; Prin, Y.; Moulin, L. Burkholderia species are the most common and preferred nodulating symbionts of the Piptadenia group (Tribe Mimoseae). PLOS ONE 2013, 8 (5), e63478.

39. Bromfield, E.S.P.; Tambong, J.T.; Cloutier, S.; Prévost, D.; Laguerre, G.; van Berkum, P.; Tran Thi, T.V.; Assabgui, R.; Barran, L.R. Ensifer, Phyllobacterium and Rhizobium species occupy nodules of Medicago sativa (alfalfa) and Melilotus alba (sweet clover) grown at a Canadian site without a history of cultivation. Microbiol. 2010, 156, 505-520.

40. Cao, Y.; Wang, E-T.; Zhao, L.; Chen, W-M.; Wei, G-H. Diversity and distribution of rhizobia nodulated with Phaseolus vulgaris in two ecoregions of China. Soil Biol. Biochem. 2014, 78, 128-137.

41. Cardinale, M.; Lanza, A.; Bonnì, M.L.; Marsala, S.; Puglia, A.M.; Quatrini, P. Diversity of rhizobia nodulating wild shrubs of Sicily and some neighbouring islands. Arch. Microbiol. 2008, 190, 461-470.

42. Cardoso, D.; Pennington, R.T.; de Queiroz, L.P.; Boatwright, J.S.; Van Wyk, B.-E.; Wojciechowski, M.F.; Lavin, M. Reconstructing the deep-branching relationships of the papilionoid legumes. S. Afr. J. Bot. 2013, 89, 58-75.

43. Chahboune, R.; Barrijal, S.; Moreno, S.; Bedmar, E.J. Characterization of Bradyrhizobium species isolated from root nodules of Cytisus villosus grown in Morocco. Syst. Appl. Microbiol. 2011, 34, 440-445.

44. Chang, Y.L.; Wang, J.Y.; Wang, E.T.; Liu, H.C.; Sui, X.H.; Chen, W.X. Bradyrhizobium lablabi sp. nov., isolated from effective nodules of Lablab purpureus and Arachis hypogaea. Int. J. Syst. Evol. Microbiol. 2011, 61, 2496-2502.

45. Chen, J.; Hu, M.; Ma, H.; Wang, Y.; Wang, E.T.; Zhou, Z.; Gu, J. Genetic diversity and distribution of bradyrhizobia nodulating peanut in acid-neutral soils in Guangdong Province. Syst. Appl. Microbiol. 2016, http://dx.doi.org/doi:10.1016/j.syapm.2016.06.002.

46. Chen, J.Y.; Gu, J.; Wang, E.T.; Ma, X.X.; Kang, S.T.; Huang, L.Z.; Cao, X.P.; Li, L.B.; Wu, Y.L. Wild peanut Arachis duranensis are nodulated by diverse and novel Bradyrhizobium species in acid soils. Syst. Appl. Microbiol. 2014, 37, 525-532.

47. Chen, W.; Sun, L.; Lu, J.; Bi, L.; Wang, E.; Wei, G. Diverse nodule bacteria were associated with Astragalus species in arid region of northwestern China. J. Basic Microbiol. 2015, 55, 121-128.

48. Chen, W.; Wang, E.; Wang, S.; Li, Y.; Chen, X.; Li, Y. Characteristics of Rhizobium tianshanense sp. nov., a moderately and slowly growing root nodule bacterium isolated from an arid saline environment in Xinjiang, People's Republic of China. Int. J. Syst. Bacteriol. 1995, 45, 153-159.

49. Chen, W-M.; de Faria, S.M.; Straliotto, R.; Pitard, R.M.; Simões-Araùjo, J.L.; Chou, J-H.; Chou, Y-J.; Barrios, E.; Prescott, A.R.; Elliott, G.N.; Sprent, J.I.; Young, J.P.W.; James, E.K. Proof that Burkholderia strains form effective symbioses with legumes: a study of novel Mimosa-nodulating strains from South America. Appl. Environ. Microbiol. 2005a, 71, 7461-7471.

50. Chen, W-M.; James, E.K.; Chou, J-H.; Sheu, S-Y.; Yang, S-Z.; Sprent, J.I. $\quad \beta$-Rhizobia from Mimosa pigra, a newly discovered invasive plant in Taiwan. New Phytol. 2005b, 168, 661-675.

51. Chen, W-M.; Lee, T-M. Genetic and phenotypic diversity of rhizobial isolates from sugarcane-Sesbania cannabina-rotation fields. Biol. Fertil. Soils. 2001, 34, 14-20.

52. Chen, W-M.; Lee, T-M.; Lan, C-C.; Cheng, C-P. Characterization of halotolerant rhizobia isolated from root nodules of Canavalia rosea from seaside areas. FEMS Microbiol. Ecol. 2000, 34, 9-16.

53. Chen, W-M.; Moulin, L.; Bontemps, C.; Vandamme, P.; Béna, G.; Boivin-Masson, C. Legume symbiotic nitrogen fixation by $\beta$-Proteobacteria is widespread in nature. J. Bacteriol. 2003, 185, 7266-7272.

54. Chen, W-X.; Tan, Z-Y.; Gao, J-L.; Li, Y.; Wang, E-T. Rhizobium hainanense sp. nov., isolated from tropical legumes. Int. J. Syst. Bacteriol. 1997, 47, 870-873.

55. Cobo-Díaz, J.F.; Martínez-Hidalgo, P.; Fernández-González, A.J.; Martínez-Molina, E.; Toro, N.; Velázquez, E.; Fernández-López, M. The endemic Genista versicolor from Sierra Nevada National Park in Spain is nodulated by putative new Bradyrhizobium species and a novel symbiovar (sierranevadense). Syst. Appl. Microbiol. 2014, 37, 177-185.

56. Cordero, I.; Ruiz-Díez, B.; de la Peña, T.C.; Balaguer, L.; Lucas, M.M.; Rincón, A.; Pueyo, J.J. Rhizobial diversity, symbiotic effectiveness and structure of nodules of Vachellia macracantha. Soil Biol. Biochem. 2016, 96, 39-54.

57. Cummings, S.P.; Gyaneshwar, P.; Vinuesa, P.; Farruggia, F.T.; Andrews, M.; Humphry, D.; Elliott, G.N.; Nelson, A.; Orr, C.; Pettitt, D.; Shah, G.R.; Santos, S.R.; Krishnan, H.B.; Odee, D.; Moreira, F.M.S.; Sprent, 
J.I.; Young, J.P.W.; James, E.K. Nodulation of Sesbania species by Rhizobium (Agrobacterium) strain IRBG74 and other rhizobia. Environ. Microbiol. 2009, 11, 2510-2525.

58. Dall'Agnol, R.F.; Plotegher, F.; Souza, R.C.; Mendes, I.C.; dos Reis Junior, F.B.; Béna, G.; Moulin, L.; Hungria, M. Paraburkholderia nodosa is the main $\mathrm{N}_{2}$-fixing species trapped by promiscuous common bean (Phaseolus vulgaris L.) in the Brazilian 'Cerradão'. FEMS Microbiol. Ecol. 2016, 92, doi: 10.1093/femsec/fiw108

59. da Silva, K.; De Meyer, S.E.; Rouws, L.F.M.; Farias, E.N.C.; dos Santos, M.A.O.; O’Hara, G.; Ardley, J.K.; Willems, A.; Pitard, R.M.; Zilli, J.E. Bradyrhizobium ingae sp. nov., isolated from effective nodules of Inga laurina grown in Cerrado soil. Int. J. Syst. Evol. Microbiol. 2014, 64, 3395-3401.

60. Degefu, T.; Wolde-meskel, E.; Frostegård, Å. Multilocus sequence analyses reveal several unnamed Mesorhizobium genospecies nodulating Acacia species and Sesbania sesban trees in Southern regions of Ethiopia. Syst. Appl. Microbiol. 2011, 34, 216-226.

61. Degefu, T.; Wolde-meskel, E.; Frostegård, Å. Phylogenetic multilocus sequence analysis identifies seven novel Ensifer genospecies isolated from a less-well-explored biogeographical region in East Africa. Int. J. Syst. Evol. Microbiol. 2012, 62, 2286-2295.

62. de Lajudie, P.; Laurent-Fulele, E.; Willems, A.; Torck, U.; Coopman, R.; Collins, M.D.; Kersters, K.; Dreyfus, B.; Gillis, M. Allorhizobium undicola gen. nov., sp. nov., nitrogen-fixing bacteria that efficiently nodulate Neptunia natans in Senegal. Int. J. Syst. Bacteriol. 1998, 48, 1277-1290.

63. Delamuta, J.R.M.; Ribeiro, R.A.; Ormeño-Orrillo, E.; Parma, M.M.; Melo, I.S.; Martínez-Romero, E.; Hungria, M. Bradyrhizobium tropiciagri sp. nov. and Bradyrhizobium embrapense sp. nov., nitrogen-fixing symbionts of tropical forage legumes. Int. J. Syst. Evol. Microbiol. 2015, 65, 4424-4433.

64. De Meyer, S.E.; Cnockaert, M.; Ardley, J.K.; Trengove, R.D.; Garau, G.; Howieson, J.G.; Vandamme, P. Burkholderia rhynchosiae sp. nov., isolated from Rhynchosia ferulifolia root nodules. Int. J. Syst. Evol. Microbiol. 2013, 63, 3944-3949.

65. De Meyer, S.E.; Tan, H.W.; Andrews, M.; Heenan, P.B.; Willems, A. Mesorhizobium calcicola sp. nov., Msorhizobium waitakense sp. nov., Mesorhizobium sophorae sp. nov., Mesorhizobium newzealandense sp. nov. and Mesorhizobium kowhaii sp. nov. isolated from Sophora root nodules in New Zealand. Int. J. Syst. Evol. Microbiol. 2016, 66, 786-795.

66. De Meyer, S.E.; Tan, H.W.; Heenan, P.B.; Andrews, M.; Willems, A. Mesorhizobium waimense sp. nov. isolated from Sophora longicarinata root nodules and Mesorhizobium cantuariense sp. nov. isolated from Sophora microphylla root nodules in New Zealand. Int. J. Syst. Evol. Microbiol. 2015, 65, 3419-3426.

67. Deng, Z.S.; Zhao, L.F.; Kong, Z.Y.; Yang, W.Q.; Lindström, K.; Wang, E.T.; Wei, G.H. Diversity of endophytic bacteria within nodules of the Sphaerophysa salsula in different regions of Loess Plateau in China. FEMS Microbiol. Ecol. 2011, 76, 463-475.

68. Diabate, M.; Munive, A.; de Faria, S.M.; Ba, A.; Dreyfus, B.; Galiana, A. Occurrence of nodulation in unexplored leguminous trees native to the West African tropical rainforest and inoculation response of native species useful in reforestation. New Phytol. 2005, 166, 231-239.

69. Diaz, L.C.; González, P.; Rubio, E.; Melchiorre, M. Diversity and stress tolerance in rhizobia from Parque Chaqueño region of Argentina nodulating Prosopis alba. Biol. Fertil. Soils 2013, 49, 1153-1165.

70. Djedidi, S.; Yokoyama, T.; Tomooka, N.; Ohkama-Ohtsu, N.; Risal, C.P.; Abdelly, C.; Sekimoto, H. Phenotypic and genetic characterization of rhizobia associated with alfalfa in the Hokkaido and Ishigaki regions of Japan. Syst. Appl. Microbiol. 2011, 34, 453-461.

71. Dobritsa, A.P.; Samadpour, M. Transfer of eleven Burkholderia species to the genus Paraburkholderia and proposal of Caballeronia gen. nov., a new genus to accommodate twelve species of Burkholderia and Paraburkholderia. Int. J. Syst. Evol. Microbiol. 2016, http://dx.doi.org/10.1099/ijsem.0.001065

72. Doignon-Bourcier, F.; Sy, A.; Willems, A.; Torck, U.; Dreyfus, B.; Gillis, M.; de Lajudie, P. Diversity of bradyrhizobia from 27 tropical Leguminosae species native of Senegal. System. Appl. Microbiol. 1999, 22, 647-661.

73. Donate-Correa, J.; Léon-Barrios, M.; Hernández, M.; Pérez-Galdona, R.; del Arco-Aguilar, M. Different Mesorhizobium species sharing the same symbiotic genes nodulate the shrub legume Anagyris latifolia. Syst. Appl. Microbiol. 2007, 30, 615-623.

74. Dos Reis Jr.F.B.; Simon, M.F.; Gross, E.; Boddey, R.M.; Elliott, G.N.; Nero, N.E.; Loureiro, M.deF.; de Queiroz, L.P.; Scotti, M.R.; Chen, W-M.; Norén, A.; Rubio, M.C.; de Faria, S.M.; Bontemps, C.; Goi, S.R.; 
Young, J.P.W.; Sprent, J.I.; James, E.K. Nodulation and nitrogen fixation by Mimosa spp. in the Cerrado and Caatinga biomes of Brazil. New Phytol. 2010, 186, 934-946.

75. Dreyfus, B.; Garcia, J.L.; Gillis, M. Characterisation of Azorhizobium caulinodans gen. nov., sp. nov., a stem nodulating nitrogen-fixing bacterium isolated from Sesbania rostrata. Int. J. Syst. Bacteriol. 1988, 38, 89-98.

76. Durán, D.; Rey, L.; Mayo, J.; Zúñiga-Dávila, D.; Imperial, J.; Ruiz-Argüeso, T.; Martínez-Romero, E.; Ormeño-Orrillo, E. Bradyrhizobium paxllaeri sp. nov. and Bradyrhizobium icense sp. nov., nitrogen-fixing rhizobial symbionts of Lima bean (Phaseolus lunatus L.) in Peru. Int. J. Syst. Evol. Microbiol. 2014, 64, 2072-2078.

77. Durán, D.; Rey, L.; Sánchez-Cañizares, C.; Navarro, A.; Imperial, J.; Ruiz-Argueso, T. Genetic diversity of indigenous rhizobial symbionts of the Lupinus mariae-josephae endemism form alkaline-limed soils within its area of distribution in Eastern Spain. Syst. Appl. Microbiol. 2013, 36, 128-136.

78. Ehinger, M.; Mohr, T.J.; Starcevich, J.B.; Sachs, J.L.; Porter, S.S.; Simms, E.L. Specialisation-generalisation trade off in a Bradyrhizobium symbiosis with wild legume hosts. BMC Ecol. 2014, 14, 8.

79. El-Akhal, M.R.; Rincón, A.; Arenal, F.; Lucas, M.M.; El Mourabit, N.; Barrijal, S.; Pueyo, J.J. Genetic diversity and symbiotic efficiency of rhizobial isolates obtained from nodules of Arachis hypogaea in northwestern Morocco. Soil Biol. Biochem. 2008, 40, 2911-2914.

80. El Batanony, N.H.; Castellano-Hinojosa, A.; Correa-Galeote, D.; Bedmar, E.J. The diversity of rhizobia nodulating the Medicago, Melilotus and Trigonella inoculation group in Egypt is marked by the dominance of two genetic types. Symbiosis 2015, 67, 3-10.

81. Elliott, G.N.; Chou, J-H.; Chen, W-M.; Bloemberg, G.V.; Bontemps, C.; Martínez-Romero, E.; Velázquez, E.; Young, J.P.W.; Sprent, J.I.; James, E.K. Burkholderia spp. are the most competitive symbionts of Mimosa, particularly under N-limited conditions. Environ. Microbiol. 2009, 11, 762-778.

82. Estrella, M.J.; Muñoz, S.; Soto, M.J.; Ruiz, O.; Sanjuán, J. Genetic diversity and host range of rhizobia nodulating Lotus tenuis in typical soils of the Salado River basin (Argentina). Appl. Environ. Microbiol. 2009, 75, 1088-1098.

83. Fall, D.; Diouf, D.; Ourarhi, M.; Faye, A.; Abdelmounen, H.; Neyra, M.; Sylla, S.N.; Missbah el Idrissi, M. Phenotypic and genotypic characteristics of Acacia Senegal (L.) Willd. root-nodulating bacteria isolated from soils in the dryland part of Senegal. Lett. Appl. Microbiol. 2008, 47, 85-97.

84. Farida, B.; Géraldine, D.; Abdelghani, B.; Djellali, B.; Said, B.; Gisèle, L. Retama species growing in different ecological-climatic areas of northeastern Algeria have a narrow range of rhizobia that form a novel phylogenetic clade within the Bradyrhizobium genus. Syst. Appl. Microbiol. 2009, 32, 245-255.

85. Fernández-López, M.; Goormachtig, S.; Gao, M.; D’Haeze, W., van Montagu, M.; Holsters, M. Ethylene-mediated phenotypic plasticity in root nodule development on Sesbania rostrata. Proc. Natl. Acad. Sci. USA. 1998, 95, 12724-12728.

86. Fonseca, M.B.; Peix, A.; de Faria, S.M.; Mateos, P.F.; Rivera, L.P.; Simões-Araujo, J.L.; França, M.G.C.; Isaias, R.M.dosS.; Cruz, C.; Velázquez, E.; Scotti, M.R.; Sprent, J.I.; James, E.K. Nodulation in Dimorphandra wilsonii Rizz. (Caesalpinioideae), a threatened species native to the Brazilian Cerrado. PLoS ONE 2012, 7 (11), e49520

87. Fornasero, L.V.; del Papa, M.F.; López, J.L.; Albicoro, F.J.; Zabala, J.M.; Toniutti, M.A.; Pensiero, J.F.; Lagares, A. Phenotypic, molecular and symbiotic characterization of the rhizobial symbionts of Desmanthus paspalaceus (Lindm.) Burkart that grow in the province of Santa Fe, Argentina. PLoS ONE 2014, 9 (8), e104636

88. Franche, C.; Lindström, K.; Elmerich, C. Nitrogen-fixing bacteria associated with leguminous and non-leguminous plants. Plant Soil. 2009, 321, 35-59.

89. Fterich, A.; Mahdhi, M.; Caviedes, M.A.; Pajuelo, E.; Rivas, R.; Rodriguez-Llorente, I.D.; Mars, M. Characterization of root-nodulating bacteria associated to Prosopis farcta growing in the arid regions of Tunisia. Arch. Microbiol. 2011, 193, 385-397.

90. Fuentes, J.B.; Abe, M.; Uchiumi, T.; Suzuki, A.; Higashi, S. Symbiotic root nodule bacteria isolated from yam bean (Pachyrhizus erosus). J. Gen. Appl. Microbiol. 2002, 48, 181-191.

91. Garau, G.; Yates, R.J.; Deiana, P.; Howieson, J.G. Novel strains of nodulating Burkholderia have a role in nitrogen fixation with papilionoid herbaceous legumes adapted to acid, infertile soils. Soil Biol. Biochem. 2009, 41, 125-134. 
92. Gehlot, H.S.; Panwar, D.; Tak, N.; Tak, A.; Sankhla, I.S.; Poonar, N.; Parihar, R.; Shekhawat, N.S.; Kumar, M.; Tiwari, R.; Ardley, J.; James, E.K.; Sprent, J.I. Nodulation of legumes from the Thar desert of India and molecular characterization of their rhizobia. Plant Soil 2012, 357, 227-243.

93. Gehlot, H.S.; Tak, N.; Kaushik, M.; Mitra, S.; Chen, W-M.; Poweleit, N.; Panwar, D.; Poonar, N.; Parihar, R.; Tak, A.; Sankhla, I.S.; Ojha, A.; Rao, S.R.; Simon, M.F.; dos Reis Junior, F.B.; Perigolo, N.; Tripathi, A.K.; Sprent, J.I.; Young, J.P.W.; James, E.K.; Gyaneshwar, P. An invasive Mimosa in India does not adopt the symbionts of its native relatives. Ann. Bot. 2013, 112, 179-196.

94. Gerding, M.; O’Hara, G.W.; Bräu, L.; Nandasena, K.; Howieson, J.G. Diverse Mesorhizobium spp. with unique nodA nodulating the South African legume species of the genus Lessertia. Plant Soil 2012, 358, 385-401.

95. Gharzouli, R.; Carpéne, M-A.; Couderc, F.; Benguedouar, A.; Poinsot, V. Relevance of fucose-rich extracellular polysaccharides produced by Rhizobium sullae strains nodulating Hedysarum coronarium L. legumes. Appl. Environ. Microbiol. 2013, 79, 1764-1776.

96. Granada, C.E.; Beneduzi, A.; Lisboa, B.B.; Turchetto-Zolet, A.C.; Vargas, L.K.; Passaglia, L.M.P. Multilocus sequence analysis reveals taxonomic differences among Bradyrhizobium sp. symbionts of Lupinus albescens plants growing in arenized and non-arenized areas. Syst. Appl. Microbiol. 2015, 38, 323-329.

97. Grönemeyer, J.L.; Kulkarni, A.; berkelmann, D.; Hurek, T.; Reinhold-Hurek, B. Rhizobia indigenous to the Okavango region in Sub-Saharan Africa: diversity, adaptations, and host specificity. Appl. Environ. Microbiol. 2014, 80, 7244-7257.

98. Gu, J.; Wang, E.T.; Chen, W.X. Genetic diversity of rhizobia associated with Desmodium species grown in China. Lett. Appl. Microbiol. 2007, 44, 286-292.

99. Guan, S.H.; Chen, W.F.; Wang, E.T.; Lu, Y.L.; Yan, X.R.; Zhang, X.X.; Chen, W.X. Mesorhizobium caraganae sp. nov., a novel rhizobial species nodulated with Caragana spp. in China. Int. J. Syst. Evol. Microbiol. 2008, 58, 2646-2653.

100. Gubry-Rangin, C.; Béna, G.; Cleyet-Merel, J-C.; Brunel, B. Definition and evolution of a new symbiovar, sv. rigiduloides, among Ensifer meliloti efficiently nodulating Medicago species. Syst. Appl. Microbiol. 2013, 36, 490-496.

101. Guerrouj, K.; Ruíz-Díez, B.; Chahboune, R.; Ramírez-Bahena, M-H.; Abdelmoumen, H.; Quiñones, M.A.; El Idrissi, M.M.; Velázquez, E.; Fernández-Pascual, M.; Bedmar, E.J.; Peix, A. Definition of a novel symbiovar (sv. retamae) within Bradyrhizobium retamae sp. nov., nodulating Retama sphaerocarpa and Retama monosperma. Syst. Appl. Microbiol. 2013, 36, 218-223.

102. Gueye, F.; Moulin, L.; Sylla, S.; Ndoye, I.; Béna, G. Genetic diversity and distribution of Bradyrhizobium and Azorhizobium strains associated with the herb legume Zornia glochidiata sampled from across Senegal. Syst. Appl. Microbiol. 2009, 32, 387-399.

103. Guimarães, A.A.; Jaramillo, P.M.D.; Nóbrega, R.S.A.; Florentino, L.A.; Silva, K.B.; Moreira, F.M.deS. Genetic and symbiotic diversity of nitrogen-fixing bacteria isolated from agricultural soils in the Western Amazon by using cowpea as the trap plant. Appl. Environ. Microbiol. 2012, 78, 6726-6733.

104. Han, L.L.; Wang, E.T.; Lu, Y.L.; Zhang, Y.F.; Sui, X.H.; Chen, W.F.; Chen, W.X. Bradyrhizobium spp. and Sinorhizobium fredii are predominant in root nodules of Vigna angularis, a native legume crop in the subtropical region of China. J. Microbiol. 2009, 47, 287-296.

105. Han, T.X.; Han, L.L.; Wu, L.J.; Chen, W.F.; Sui, X.H.; Gu, J.G.; Wang, E.T.; Chen, W.X. Mesorhizobium gobiense sp. nov. and Mesorhizobium tarimense sp. nov., isolated from wild legumes growing in desert soils of Xinjiang, China. Int. J. Syst. Evol. Microbiol. 2008a, 58, 2610-2618.

106. Han, T.X.; Wang, E.T.; Wu, L.J.; Chen, W.F.; Gu, J.G.; Gu, C.T.; Tian, C.F.; Chen, W.X. Rhizobium multihospitium sp. nov., isolated from multiple legume species native of Xinjiang, China. Int. J. Syst. Evol. Microbiol. 2008b, 58, 1693-1699.

107. Hassen, A.I.; Bopape, F.L.; Habig, J.; Lamprecht, S.C. Nodulation of rooibos (Aspalathus linearis Burm. f.), an indigenous South African legume, by members of both the $\alpha$-Proteobacteria and $\beta$-Proteobacteria. Biol. Fertil. Soils 2012, 48, 295-303.

108. Helene, L.C.F.; Delamuta, J.R.M.; Ribeiro, R.A.; Ormeño-Orrillo, E.; Rogel, M.A.; Martínez-Romero, E.; Hungria, M. Bradyrhizobium viridifuturi sp. nov., encompassing nitrogen-fixing symbionts of legumes used for green manure and environmental services. Int. J. Syst. Evol. Microbiol. 2015, 65, 4441-4448. 
109. Horn, K.; Parker, I.M.; Malek, W.; Rodríguez-Echeverria, S.; Matthew, A.P. Disparate origins of Bradyrhizobium symbionts for invasive populations of Cytisus scoparius (Leguminosae) in North America. FEMS Microbiol. Ecol. 2014, 89, 89-98.

110. Howieson, J.G.; De Meyer, S.E.; Vivas-Marfisi, A.; Ratnayake, S.; Ardley, J.K.; Yates, R.J. Novel Burkholderia bacteria isolated from Lebeckia ambigua - A perennial suffrutescent legume of the fynbos. Soil Biol. Biochem. 2013, 60, 55-64.

111. Huang, B.; Lv, C.; Zhao, Y.; Huang, R. A novel strain D5 isolated from Acacia confusa. PLoS ONE 2012, 7 (11), e49236.

112. Iglesias, O.; Rivas, R.; García-Fraile, P.; Abril, A.; Mateos, P.F.; Martinez-Molina, E.; Velázquez, E. Genetic characterization of fast-growing rhizobia able to nodulate Prosopis alba in North Spain. FEMS Microbiol. Lett. 2007, 277, 210-216.

113. Jackson, L.E.; Burger, M.; Cavagnaro, T.R. Roots, nitrogen transformations, and ecosystem services. Ann. Rev. Plant Biol. 2008, 59, 341-363.

114. Jaiswal, S.K.; Anand, A.; Dhar, B.; Vaishampayan, A. Genotypic characterization of phage-typed indigenous soybean Bradyrhizobia and their host range symbiotic effectiveness. Microb. Ecol. 2012, 63, 116-126.

115. Jarabo-Lorenzo, A.; Pérez-Galdona, R.; Donate-Correa, J.; Rivas, R.; Velázquez, E.; Hernández, M.; Temprano, F.; Martínez-Molina, E.; Ruiz-Argüeso, T.; Léon-Barrios, M. Genetic diversity of Bradyrhizobial populations from diverse geographic origins that nodulate Lupinus spp. and Ornithopus spp. System. Appl. Microbiol. 2003, 26, 611-623.

116. Jarabo-Lorenzo, A.; Velázquez, E.; Pérez-Galdona, R.; Vega-Hernández, M.C.; Martínez-Molina, E.; Mateos, P.F.; Vinuesa, P.; Martínez-Romero, E.; Léon-Barrios, M. Restriction fragment length polymorphism analysis of $16 \mathrm{~S}$ rDNA and low molecular weight RNA profiling of rhizobial isolates from shrubby legumes endemic to the Canary Islands. System. Appl. Microbiol. 2000, 23, 418-425.

117. Jarvis, B.D.W.; van Berkum, P.; Chen, W.X.; Nour, S.M.; Fernandez, M.P.; Cleyet-Marel, J.C.; Gillis, M. Transfer of Rhizobium loti, Rhizobium huakuii, Rhizobium ciceri, Rhizobium mediterraneum, and Rhizobium tianshanense to Mesorhizobium gen. nov. Int. J. Syst. Bacteriol. 1997, 47, 895-898.

118. Jiao, Y.S.; Liu, Y.H.; Yan, H.; Wang, E.T.; Tian, C.F.; Chen, W.X.; Guo, B.L.; Chen, W.F. Rhizobial diversity and nodulation characteristics of the extremely promiscuous legume Sophora flavescens. Mol. Plant Microbe Interact. 2015a, 28, 1338-1352.

119. Jiao, Y.S.; Yan, H.; Ji, Z.J.; Liu, Y.H.; Sui, X.H.; Zhang, X.X.; Wang, E.T.; Chen, W.X.; Chen, W.F. Phyllobacterium sophorae sp. nov., a symbiotic bacterium isolated from root nodules of Sophora flavescens. Int. J. Syst. Evol. Microbiol. 2015b, 65, 399-406.

120. Kalita, M.; Malek, W.; Kaznowski, A. Analysis of genetic relationship of Sarothamnus scoparius microsymbionts and Bradyrhizobium sp. by hybridization in microdilution wells. J. Biosci. Bioeng. 2004, 97, 158-161.

121. Kan, F.L.; Chen, Z.Y.; Wang, E.T.; Tian, C.F.; Sui, X.H.; Chen, W.X. Characterization of symbiotic and endophytic bacteria isolated from root nodules of herbaceous legumes grown in Qinghai-Tibet plateau and in other zones of China. Arch. Microbiol. 2007, 188, 103-115.

122. Kanu, S.A.; Dakora, F.D. Symbiotic nitrogen contribution and biodiversity of root-nodule bacteria nodulating Psoralea species in the Cape Fynbos, South Africa. Soil Biol. Biochem. 2012, 54, 68-76.

123. Keller, K.R. Mutualistic rhizobia reduce plant diversity and alter community composition. Oecologia, 2014, 176, 1101-1109.

124. Kesari, V.; Ramesh, A.M.; Rangan, L. Rhizobium pongamiae sp. nov. from root nodules of Pongamia pinnata. Biomed Res. Int. 2013, 2013, 165198.

125. Khbaya, B.; Neyra, M.; Normand, P.; Zerhari, K.; Filali-Maltouf, A. Genetic diversity and phylogeny of rhizobia that nodulate Acacia spp. in Morocco assessed by analysis of rRNA genes. Appl. Environ. Microbiol. 1998, 64, 4912-4917.

126. Lafay, B.; Burdon, J.J. Molecular diversity of legume root-nodule bacteria in Kakadu National Park, Northern Territory, Australia. PLoS ONE 2007, 3, e277.

127. Leblanc, H.A.; McGraw, R.L.; Nygren, P.; Le Roux, C. Neotropical legume tree Inga edulis forms $\mathrm{N}_{2}$-fixing symbiosis with fast-growing Bradyrhizobium strains. Plant Soil 2005, 275, 123-133.

128. Lei, X.; Wang, E.T.; Chen, W.F.; Sui, X.H.; Chen, W.X. Diverse bacteria isolated from root nodules of wild Vicia species grown in temperate region of China. Arch. Microbiol. 2008, 190, 657-671. 
129. Lemaire, B.; Dlodlo, O.; Chimphango, S.; Stirton, C.; Schrire, B.; Boatwright, J.S.; Honnay, O.; Smets, E.; Sprent, J.; James, E.K.; Muasya, A.M. Symbiotic diversity, specificity and distribution of rhizobia in native legumes of the Core Cape Subregion (South Africa). FEMS Microbiol. Ecol. 2015, 91, 1-17.

130. Lemaire, B.; Van Cauwenberghe J.; Verstraete, B.; Chimphango, S.; Stirton, C.; Honnay, O.; Smets, E.; Sprent, J.; James, E.K.; Muasya, A.M. Characterization of the papilionoid-Burkholderia interaction in the Fynbos biome: The diversity and distribution of beta-rhizobia nodulating Podalyria calyptrata (Fabaceae, Podalyrieae). Syst. Appl. Microbiol. 2016, 39, 41-48.

131. Léon-Barrios, M.; Lorite, M.J.; Donate-Correa, J.; Sanjuán, J. Ensifer meliloti bv. lancerottense establishes nitrogen-fixing symbiosis with Lotus endemic to the Canary Islands and shows distinctive symbiotic genotypes and host range. Syst. Appl. Microbiol. 2009, 32, 413-420.

132. Le Roux, C.; Muller, F.; Bouvet, J-M.; Dreyfus, B.; Béna, G.; Galiana, A.; Bâ, A.M. Genetic diversity patterns and functional traits of Bradyrhizobium strains associated with Pterocarpus officinalis Jacq. in Caribbean islands and Amazonian forest (French Guiana). Microb. Ecol. 2014, 68, 329-338.

133. Le Roux, C.; Tentchev, D.; Prin, Y.; Goh, D.; Japarudin, Y.; Perrineau, M-M.; Duponnois, R.; Domergue, O.; de Lajudie, P.; Galiana, A. Bradyrhizobia nodulating the Acacia mangium $\times$ A. auriculiformis interspecific hybrid are specific and differ from those associated with both parental species. Appl. Environ. Microbiol. 2009, 75, 7752-7759.

134. Lewis, G., A.; Schrire, B.B.; Mackinder, B., C.; Lock, M., D. Legumes of the World.; Kew: Royal Botanic Gardens. 2005.

135. Li, Y.; Li, X.; Liu, Y.; Wang, E.T.; Ren, C.; Liu, W.; Xu, H.; Wu, H.; Jiang, N.; Li, Y.; Zhang, X.; Xie, Z. Genetic diversity and community structure of rhizobia nodulating Sesbania cannabina in saline-alkaline soils. Syst. Appl. Microbiol. 2016, 39, 195-202.

136. Li, L.; Sinkko, H.; Montonen, L.; Wei, G.; Lindström, K.; Räsänen, L.A. Biogeography of symbiotic and other endophytic bacteria isolated from medicinal Glycyrrhiza species in China. FEMS Microbiol. Ecol. 2012, 79, 46-68.

137. Li, Q.Q.; Wang, E.T.; Chang, Y.L.; Zhang, Y.Z.; Zhang, Y.M.; Sui, X.H.; Chen, W.F.; Chen, W.X. Ensifer sojae sp. nov., isolated from root nodules of Glycine max grown in saline-alkaline soils. Int. J. Syst. Evol. Microbiol. 2011, 61, 1981-1988.

138. Li, Y.H.; Wang, R.; Zhang, X.X.; Young, J.P.W.; Wang, E.T.; Sui, X.H.; Chen, W.X. Bradyrhizobium guangdongense sp. nov. and Bradyrhizobium guangxiense sp. nov., isolated from effective nodules of peanut. Int. J. Syst. Evol. Microbiol. 2015, 65, 4655-4661.

139. Lin, D.X.; Man, C.X.; Wang, E.T.; Chen, W.X. Diverse rhizobia that nodulate two species of Kummerowia in China. Arch. Microbiol. 2007, 188, 495-507.

140. Lindström, K. Rhizobium galegae, a new species of legume root nodule bacteria. Int. J. Syst. Bacteriol. 1989, 39, 365-367.

141. Lindström, K.; Aserse, A.A.; Mousavi, S.A. Evolution and taxonomy of nitrogen-fixing organisms with emphasis on rhizobia. In Biological Nitrogen Fixation, $1^{\text {st }}$ ed., de Bruijn, F.J., Ed.; Wiley \& Sons, Inc.: Hoboken, New Jersey, 2015; pp. 21-37.

142. Liu, X.Y.; Wang, E.T.; Li, Y.; Chen, W.X. Diverse bacteria isolated from root nodules of Trifolium, Crotalaria and Mimosa grown in the subtropical regions of China. Arch. Microbiol. 2007, 188, 1-14.

143. Liu, X.Y.; Wei, S.; Wang, F.; James, E.K.; Guo, X.Y.; Zagar, C.; Xia, L.G.; Dong, X.; Wang, Y.P. Burkholderia and Cupriavidus spp. are the preferred symbionts of Mimosa spp. in Southern China. FEMS Microbiol. Ecol. 2012, 80, 417-426.

144. Liu, X.Y.; Wu, W.; Wang, E.T.; Zhang, B.; Macdermott, J.; Chen, W.X. Phylogenetic relationships and diversity of $\beta$-rhizobia associated with Mimosa species grown in Sishuangbanna, China. Int. J. Syst. Evol. Microbiol. 2011, 61, 334-342.

145. Liu, W.Y.Y. Characterisation of rhizobia and studies on $\mathrm{N}_{2}$ fixation of common weed legumes in New Zealand. PhD thesis, Lincoln University, New Zealand, 2014.

146. Liu, W.Y.Y.; Ridgway, H.J.; James, T.K.; James, E.K.; Chen, W-M.; Sprent, J.I.; Young, J.P.W.; Andrews, M. Burkholderia sp. induces functional nodules on the South African invasive legume Dipogon lignosus (Phaseoleae) in New Zealand soils. Microb. Ecol. 2014, 68, 542-555.

147. Liu, W.Y.Y.; Ridgway, H.J.; James, T.K.; Premaratne, M.; Andrews, M. Characterisation of rhizobia nodulating Galega officinalis (goat's rue) and Hedysarum coronarium (sulla). NZ Plant Protection 2012, 65, 192-196. 
148. Lloret, L.; Ormeño-Orillo, E.; Rincón, R.; Martinez-Romero, J.; Rogel-Hernández, M.A.; Martinez-Romero, E. Ensifer mexicanus sp. nov. a new species nodulating Acacia angustissima (Mill.) Kuntze in Mexico. Syst. Appl. Microbiol. 2007, 30, 280-290.

149. López-López, A.; Negrete-Yankelevich, S.; Rogel, M.A.; Ormeño-Orrillo, E.; Martínez, J.; Martínez-Romero, E. Native bradyrhizobia from Los Tuxtlas in Mexico are symbionts of Phaseolus lunatus (Lima bean). Syst. Appl. Microbiol. 2013, 36, 33-38.

150. López-López, A.; Rogel-Hernández, M.A.; Barois, I.; Ortis Ceballos, A.I.; Martínez, J.; Ormeño-Orrillo, E.; Martínez-Romero, E. Rhizobium grahamii sp. nov., from nodules of Dalea leporina, Leucaena leucocephala and Clitoria ternatea, and Rhizobium mesoamericanum sp. nov., from nodules of Phaseolus vulgaris, siratro, cowpea and Mimosa pudica. Int. J. Syst. Evol. Microbiol. 2012, 62, 2264-2271.

151. Lorite, M.J.; Donate-Correa, J.; del Arco-Aguilar, M.; Galdona, R.P.; Sanjuán, J.; Léon-Barrios, M. Lotus endemic to the Canary Islands are nodulated by diverse and novel rhizobial species and symbiotypes. Syst. Appl. Microbiol. 2010a, 33, 282-290.

152. Lorite, M.J.; Muñoz, S.; Olivares, J.; Soto, M.J.; Sanjuán, J. Characterization of strains unlike Mesorhizobium loti that nodulate Lotus spp. in saline soils of Granada, Spain. Appl. Environ. Microbiol. 2010b, 76, 4019-4026.

153. Lorite, M.J.; Videira e Castro, I.; Muñoz, S.; Sanjuán, J. Phylogenetic relationship of Lotus uliginosus symbionts with bradyrhizobia nodulating genistoid legumes. FEMS Microbiol. Ecol. 2012, 79, 454-464.

154. Lortet, G.; Méar, N.; Lorquin, J.; Dreyfus, B.; de Lajudie, P.; Rosenberg, C.; Boivin, C. Nod factor thin-layer chromatography profiling as a tool to characterize symbiotic specificity of rhizobial strains: application to Sinorhizobium saheli, S. teranga, and Rhizobium sp. strains isolated from Acacia and Sesbania. Mol. Plant-Microbe Interact. 1996, 9, 736-747.

155. LPWG. Legume phylogeny and classification in the $21^{\text {st }}$ century: Progress, prospects and lessons for other species-rich clades. TAXON 2013, 62, 217-248.

156. Lu, Y.L.; Chen, W.F.; Wang, E.T.; Guan, S.H.; Yan, X.R.; Chen, W.X. Genetic diversity and biogeography of rhizobia associated with Caragana species in three ecological regions of China. Syst. Appl. Microbiol. 2009, 32, 351-361.

157. Lu, J.K.; Dou, Y.J.; Zhu, Y.J.; Wang, S.K.; Sui, X.H.; Kang, L.H. Bradyrhizobium ganzhouense sp. nov., an effective symbiotic bacterium isolated from Acacia melanoxylon R. Br. nodules. Int. J. Syst. Evol. Microbiol. 2014, 64, 1900-1905.

158. Lu, J.K.; He, X.H.; Huang, L.B.; Kang, L.H.; Xu, D.P. Two Burkholderia strains from nodules of Dalbergia odorifera T. Chen in Hainan Island, southern China. New Forests 2012, 43, 397-409.

159. Maâtallah, J.; Berraho, E.B.; Muñoz, S.; Sanjuan, J.; Lluch, C. Phenotypic and molecular characterization of chickpea rhizobia isolated from different areas of Morocco. J. Appl. Microbiol. 2002, 93, 531-540.

160. Manassila, M.; Nuntagij, A.; Kotepong, S.; Boonkerd, N.; Teaumroong, N. Characterization and monitoring of selected rhizobial strains isolated from tree legumes in Thailand. Afr. J. Biotechnol. 2007, 6, 1393-1402.

161. Marcos-García, M.; Menéndez, E.; Cruz-González, X.; Velázquez, E.; Mateos, P.F.; Rivas, R. The high diversity of Lotus corniculatus endosymbionts in soils of northwest Spain. Symbiosis 2015, 67, 11-20.

162. Marsudi, N.D.S.; Glenn, A.R.; Dilworth, M.J. Identification and characterization of fast- and slow-growing root nodule bacteria from South-Western Australian soils able to nodulate Acacia saligna. Soil Biol. Biochem. 1999, 31, 1229-1238.

163. Martens, M.; Delaere, M.; Coopman, R.; De Vos, P.; Gillis, M.; Willems, A. Multilocus sequence analysis of Ensifer and related taxa. Int. J. Syst. Evol. Microbiol. 2007, 57, 489-503.

164. Martínez-Romero, E. Diversity of Rhizobium-Phaseolus vulgaris symbiosis: overview and perspectives. Plant Soil 2003, 252, 11-23.

165. Martínez-Romero, E.; Segovia, L.; Mercante, F.M.; Franco, A.A.; Graham, P.; Pardo, M.A. Rhizobium tropici, a novel species nodulating Phaseolus vulgaris L. beans and Leucaena sp. trees. Int. J. System. Bacteriol. 1991, 41, 417-426.

166. Masson-Boivin, C.; Giraud, E.; Perret, X.; Batut, J. Establishing nitrogen-fixing symbiosis with legumes: how many rhizobium recipes? Trends Microbiol. 2009, 17, 10.

167. Matsubara, M.; Zúñiga-Dávila, D. Phenotypic and molecular differences among rhizobia that nodulate Phaseolus lunatus in the Supe valley in Peru. Ann. Microbiol. 2015, 65, 1803-1808. 
168. Merabet, C.; Martens, M.; Mahdi, M.; Zakhia, F.; Sy, A.; Le Roux, C.; Domergue, O.; Coopman, R.; Bekki, A.; Mars, M.; Willems, A.; de Lajudie, P. Multilocus sequence analysis of root nodule isolates from Lotus arabicus (Senegal), Lotus creticus, Argyrolobium uniflorum and Medicago sativa (Tunisia) and description of Ensifer numidicus sp. nov. and Ensifer garamanticus sp. nov. Int. J. Syst. Evol. Microbiol. 2010, 60, 664-674.

169. Mhamdi, R.; Laguerre, G.; Aouani, M.E.; Mars, M.; Amarger, N. Different species and symbiotic genotypes of field rhizobia can nodulate Phaseolus vulgaris in Tunisian soils. FEMS Microbiol. Ecol. 2002, 41, 77-84.

170. Michalk, D.L.; Zhi-Kai, H. Grassland improvement in subtropical Guangdong Province, China. 1. Evaluation of pasture legumes. Tropical Grasslands, 1994, 28, 129-138.

171. Miché, L.; Moulin, L.; Chaintreuil, C.; Contreras-Jimenez, J.L.; Munive-Hernández, J-A.; Villegas-Hernandez, M.delC.; Crozier, F.; Béna, G. Diversity analyses of Aeschynomene symbionts in Tropical Africa and Central America reveal that nod-independent stem nodulation is not restricted to photosynthetic bradyrhizobia. Symbiosis 2010, 12, 2152-2164.

172. Mierzwa, B.; Wdowiak-Wróbel, S.; Malek, W. Phenotypic, genomic and phylogenetic characteristics of rhizobia isolated from root nodules of Robinia pseudoacacia (black locust) growing in Poland and Japan. Arch. Microbiol. 2009, 191, 697-710.

173. Mnasri, B.; Saïdi, S.; Chihaoui, S-A.; Mhamdi, R. Sinorhizobium americanum symbiovar mediterranense is a predominant symbiont that nodulates and fixes nitrogen with common bean (Phaseolus vulgaris L.) in a Northern Tunisian field. Syst. Appl. Microbiol. 2012, 35, 263-269.

174. Mnasri, B.; Badri, Y.; Saïdi, S.; de Lajudie, P.; Mhamdi, R. Symbiotic diversity of Ensifer meliloti strains recovered from various legume species in Tunisia. Syst. Appl. Microbiol. 2009, 32, 583-592.

175. Mnasri, B.; Mrabet, M.; Laguerre, G.; Aouani, M.E.; Mhamdi, R. Salt-tolerant rhizobia isolated from a Tunisian oasis that are highly effective for symbiotic $\mathrm{N}_{2}$-fixation with Phaseolus vulgaris constitute a novel biovar (bv. mediterranense) of Sinorhizobium meliloti. Arch. Microbiol. 2007, 187, 79-85.

176. Montecchia, M.S.; Kerber, N.L.; Pucheu, N.L.; Perticari, A.; García, A.F. Analysis of genomic diversity among photosynthetic stem-nodulating rhizobial strains from Northeast Argentina. 2002, 25, 423-433.

177. Moreira, F.M.deS.; Cruz, L.; de Faria, S.M.; Marsh, T.; Martínez-Romero, E.; Pedrosa, F.deO.; Pitard, R.M.; Young, J.P.W. Azorhizobium doebereinerae sp. nov. microsymbiont of Sesbania virgata (Caz.) Pers. Syst. Appl. Microbiol. 2006, 29, 197-206.

178. Mostasso, L.; Mostasso, F.L.; Dias, B.G.; Vargas, M.A.T.; Hungria, M. Selection of bean (Phaseolus vulgaris L.) rhizobial strains for the Brazilian Cerrados. Field Crops Res. 2002, 73, 121-132.

179. Muñoz, V.; Ibañez, F.; Tonelli, M.L.; Valetti, L.; Anzuay, M.S.; Fabra, A. Phenotypic and phylogenetic characterization of native peanut Bradyrhizobium isolates obtained from Córdoba, Argentina. Syst. Appl. Microbiol. 2011, 34, 446-452.

180. Mutch, L.A.; Young, J.P.W. Diversity and specificity of Rhizobium leguminosarum biovar viciae on wild and cultivated legumes. Mol. Ecol. 2004, 13, 2435-2444.

181. Nandasena, K.G.; O'Hara, G.W.; Tiwari, R.P.; Willems, A.; Howieson, J.G. Mesorhizobium australicum sp. nov. and Mesorhizobium opportunistum sp. nov., isolated from Biserrula pelecinus L. in Australia. Int. J. Syst. Evol. Microbiol. 2009, 59, 2140-2147.

182. Nandasena, K.G.; O’Hara, G.W.; Tiwari, R.P.; Yates, R.J.; Howieson, J.G. Phylogenetic relationships of three bacterial strains isolated from the pasture legume Biserrula pelecinus L. Int. J. Syst. Evol. Microbiol. 2001, 51, 1983-1986.

183. Ngom, A.; Nakagawa, Y.; Sawada, H.; Tsukahara, J.; Wakabayashi, S.; Uchiumi, T.; Nuntagij, A.; Kotepong, S.; Suzuki, A.; Higashi, S.; Abe, M. A novel symbiotic nitrogen-fixing member of the Ochrobactrum clade isolated from root nodules of Acacia mangium. J. Gen. Appl. Microbiol. 2004, 50, 17-27.

184. Nick, G.; de Lajudie, P.; Eardly, B.D.; Suomalainen, S.; Paulin, L.; Zhang, X.; Gillis, M.; Lindström, K. Sinorhizobium arboris sp. nov. and Sinorhizobium kostiense sp. nov., isolated from leguminous trees in Sudan and Kenya. Int. J. Syst. Bacterial. 1999, 49, 1359-1368.

185. Noisangiam, R.; Teamtisong, K.; Tittabutr, P.; Boonkerd, N.; Toshiki, U.; Minamisawa, K.; Teaumroong, N. Genetic diversity, symbiotic evolution, and proposed infection process of Bradyrhizobium strains isolated from root nodules of Aeschynomene americana L. in Thailand. Appl. Environ. Microbiol. 2012, 78, 6236-6250.

186. Nour, S.M.; Fernandez, M.P.; Normand, P.; Cleyet-Marel, J-C. Rhizobium ciceri sp. nov., consisting of strains that nodulate chickpeas (Cicer arietinum L.). Int. J. Syst. Bacteriol. 1994, 44, 511-522. 
187. Odee, D.W.; Haukka, K.; McInroy, S.G.; Sprent, J.I.; Sutherland, J.M.; Young, J.P.W. Genetic and symbiotic characterization of rhizobia isolated from tree and herbaceous legumes grown in soils from ecologically diverse sites in Kenya. Soil Biol. Biochem. 2002, 34, 801-811.

188. Ogasawara, M.; Suzuki, T.; Mutoh, I., Annapurna, K.; Arora, N.K.; Nishimura, Y.; Maheshwari, D.K. Sinorhizobium indiaense sp. nov. and Sinorhizobium abri sp. nov. isolated from tropical legumes, Sesbania rostrata and Abrus precatorius, respectively. Symbiosis 2003, 34, 53-68.

189. Onyango, B.; Anyango, B.; Nyunja, R.; Koech, P.K.; Skilton, R.A.; Stomeo, F. Morphological, genetic and symbiotic characterization of root nodule bacteria isolated from Bambara groundnuts (Vigna subterranea $\mathrm{L}$. Verdc) from soils of Lake Victoria basin, western Kenya. J. Appl. Biol. Biotechnol. 2015, 3, 1-10.

190. Oren, A.; Garrity, G.M. List of new names and new combinations previously effectively, but not validly, published. Int. J. Syst. Evol. Microbiol. 2015, 65, 2017-2025.

191. Ourarhi, M.; Abdelmoumen, H.; Guerrouj, K.; Benata, H.; Muresu, R.; Squartini, A.; El Idrissi, M.M. Colutea arborescens is nodulated by diverse rhizobia in Eastern Morocco. Arch. Microbiol. 2011, 193, 115-124.

192. Parker, M.A. Divergent Bradyrhizobium symbionts on Tachigali versicolor from Barro Colorado Island, Panama. System. Appl. Microbiol. 2000, 23, 585-590.

193. Parker, M.A.; Doyle, J.L.; Doyle, J.J. Comparative phylogeography of Amphicarpaea legumes and their root-nodule symbionts in Japan and North America. J. Biogeogr. 2004, 31, 425-434.

194. Parker, M.A.; Wurtz, A.K.; Paynter, Q. Nodule symbiosis of invasive Mimosa pigra in Australia and in ancestral habitats: a comparative analysis. Biol. Invasions 2007, 9, 127-138.

195. Peng, G.X.; Tan, Z.Y.; Wang, E.T.; Reinhold-Hurek, B.; Chen, W.F.; Chen, W.X. Identification of isolates from soybean nodules in Xinjiang Region as Sinorhizobium xinjiangense and genetic differentiation of $S$. xinjiangense from Sinorhizobium fredii. Int. J. Syst. Evol. Microbiol. 2002, 52, 457-462.

196. Platero, R.; James, E.K.; Rios, C.; Iriarte, A.; Sandes, L.; Zabaleta, M.; Battistoni, F.; Fabiano, E. Novel Cupriavidus strains isolated from root nodules of native Uruguayan Mimosa species. Appl. Environ. Microbiol. 2016, doi:10.1128/AEM.04142-15

197. Quatrini, P. Scaglione, G.; Cardinale, M.; Caradonna, F. Puglia, A.M. Bradyrhizobium sp. nodulating the Mediterranean shrub Spanish broom (Spartium junceum L.) J. Appl. Microbiol. 2002, 92, 13-21.

198. Radeva, G.; Jurgens, G.; Niemi, M.; Nick, G.; Suominen, L.; Lindström, K. Description of two biovars in the Rhizobium galegae species: biovar orientalis and biovar officinalis. System. Appl. Microbiol. 2001, 24, 192-205.

199. Ramírez-Bahena, M.H.; Peix, A.; Rivas, R.; Camacho, M.; Rodríguez-Navarro, D.N.; Mateos, P.F.; Martínez-Molina, E.; Willems, A.; Velázquez, E. Bradyrhizobium pachyrhizi sp. nov. and Bradyrhizobium jicamae sp. nov., isolated from effective nodules of Pachyrhizus erosus. Int. J. Syst. Evol. Microbiol. 2009, 59, 1929-1934.

200. Räsänen, L.A.; Sprent, J.I.; Lindström, K. Symbiotic properties of sinorhizobia isolated from Acacia and Prosopis nodules in Sudan and Senegal. Plant Soil 2001, 235, 193-210.

201. Rashid, M.H.; Schäfer, H.; Gonzalez, J.; Wink, M. Genetic diversity of rhizobia nodulating lentil (Lens culinaris) in Bangladesh. Syst. Appl. Microbiol. 2012, 35, 98-109.

202. Rasolomampianina, R.; Bailly, X.; Fetiarison, R.; Rabevohitra, R.; Béna, G.; Ramaroson, L.; Raherimandimby, M.; Moulin, L.; de Lajudie, P.; Dreyfus, B.; Avarre, J.-C. Nitrogen-fixing nodules from rose wood legume trees (Dalbergia spp.) endemic to Madagascar host seven different genera belonging to $\alpha$ - and $\beta$-Proteobacteria. Mol. Ecol. 2005, 14, 4135-4146.

203. Raven, J.A. Why are mycorrhizal fungi and symbiotic nitrogen-fixing bacteria not genetically integrated into plants? Ann. Appl. Biol. 2010, 157, 381-391.

204. Rejili, M.; Mahdhi, M.; Fterich, A.; Dhaoui, S.; Guefrachi, I.; Abdeddayem, R.; Mars, M. Symbiotic nitrogen fixation of wild legumes in Tunisia: Soil fertility dynamics, field nodulation and nodules effectiveness. Agric. Ecosyst. Environ. 2012, 157, 60-69.

205. Remigi, P.; Zhu, J.; Young, J.P.W.; Masson-Boivin, C. Symbiosis within symbiosis: evolving nitrogen-fixing legume symbionts. Trends Microbiol. 2016, 24, 63-75.

206. Riah, N.; Béna, G.; Djekoun, A.; Heulin, K.; de Lajudie, P.; Laguerre, G. Genotypic and symbiotic diversity of Rhizobium populations associated with cultivated lentil and pea in sub-humid and semi-arid regions of Eastern Algeria. Syst. Appl. Microbiol. 2014, 37, 368-375. 
207. Ribeiro, P.R.deA.; dos Santos, J.V.; da Costa, E.M.; Lebbe, L.; Assis, E.S.; Louzada, M.O.; Guimarães, A.A.; Willems, A.; Moreira, F.M.deS. Symbiotic efficiency and genetic diversity of soybean bradyrhizobia in Brazilian soils. Agric. Ecosyst. Environ. 2015, 212, 85-93.

208. Ribeiro, R.A.; Ormeño-Orrillo, E.; Dall'Agnol, R.F.; Graham, P.H.; Martinez-Romero, E.; Hungria, M. Novel Rhizobium lineages isolated from root nodules of the common bean (Phaseolus vulgaris L.) in Andean and Mesoamerican areas. Res. Microbiol. 2013, 164, 740-748.

209. Rincón-Rosales, R.; Lloret, L.; Ponce, E.; Martínez-Romero, E. Rhizobia with different symbiotic efficiencies nodulate Acaciella angustissima in Mexico, including Sinorhizobium chiapanecum sp. nov. which has common symbiotic genes with Sinorhizobium mexicanum. FEMS Microbiol. Ecol. 2009, 67, 103-117.

210. Rincón-Rosales, R.; Villalobos-Escobedo, J.M.; Rogel, M.A.; Martinez, J.; Ormeño-Orrillo, E.; Martínez-Romero, E. Rhizobium calliandrae sp. nov., Rhizobium mayense sp. nov. and Rhizobium jaguaris sp. nov., rhizobial species nodulating the medicinal legume Calliandra grandiflora. Int. J. Syst. Evol. Microbiol. 2013, 63, 3423-3429.

211. Risal, C.P.; Djedidi, S.; Dhakal, D.; Ohkama-Ohtsu, N.; Sekimoto, H.; Yokoyama, T. Phylogenetic diversity and symbiotic functioning in mungbean (Vigna radiata L. Wilczek) bradyrhizobia from contrast agro-ecological regions of Nepal. Syst. Appl. Microbiol. 2012, 35, 45-53.

212. Rivas, R.; Laranjo, M.; Mateos, P.F.; Oliveira, S.; Martinez-Molina, E.; Velázquez, E. Strains of Mesorhizobium amorphae and Mesorhizobium tianshanense, carrying symbiotic genes of common chickpea endosymbiotic species, constitute a novel biovar (ciceri) capable of nodulating Cicer arietinum. Lett. Appl. Microbiol. 2007, 44, 412-418.

213. Rivas, R.; Velázquez, E.; Willems, A.; Vizcaíno, N.; Subba-Rao, N.S.; Mateos, P.F.; Gillis, M.; Dazzo, F.B.; Martínez-Molina, E. A new species of Devosia that forms a unique nitrogen-fixing root-nodule symbiosis with the aquatic legume Neptunia natans (L.f.) Druce. Appl. Environ. Microbiol. 2002, 68, 5217-5222.

214. Rodríguez-Echeverría, S.; Moreno, S.; Bedmar, E.J. Genetic diversity of root nodulating bacteria associated with Retama sphaerocarpa in sites with different soil and environmental conditions. Syst. Appl. Microbiol. 2014, 37, 305-310.

215. Rodríguez-Echeverría, S.; Pérez-Fernández, M.A.; Vlaar, S.; Finnan, T. Analysis of the legume-rhizobia symbiosis in shrubs from central western Spain. J. Appl. Microbiol. 2003, 95, 1367-1374.

216. Rodríguez-Navarro, D.N.; Camacho, M.; Leidi, E.O.; Rivas, R.; Velázquez, E. Phenotypic and genotypic characterization of rhizobia from diverse geographical origin that nodulate Pachyrhizus species. System. Appl. Microbiol. 2004, 27, 737-745.

217. Rogel, M.A.; Ormeño-Orrillo, E.; Martinez-Romero, E. Symbiovars in rhizobia reflect bacterial adaptation to legumes. Syst. Appl. Microbiol. 2011, 34, 96-104.

218. Rome, S.; Fernandez, M.P.; Brunel, B.; Normand, P.; Cleyet-Marel, J-C. Sinorhizobium medicae sp. nov., isolated from annual Medicago spp. Int. J. Syst. Bacteriol. 1996, 46, 972-980.

219. Ruiz-Díez, B.; Fajardo, S.; Puertas-Mejía, M.A.; de Felipe, M.delR.; Fernández-Pascual, M. Stress tolerance, genetic analysis and symbiotic properties of root-nodulating bacteria isolated from Mediterranean leguminous shrubs in Central Spain. Arch. Microbiol. 2009, 191, 35-46.

220. Ryan-Salter, T.P.; Black, A.D.; Andrews, M.; Moot, D.J. Identification and effectiveness of rhizobial strains that nodulate Lupinus polyphyllus. Proc. NZ Grassland Assoc. 2014, 76, 61-66.

221. Saïdi, S.; Chebil, S.; Gtari, M.; Mhamdi, R. Characterization of root-nodule bacteria isolated from Vicia faba and selection of plant growth promoting isolates. World J. Microbiol. Biotechnol. 2013, 29, 1099-1106.

222. Saidi, S.; Ramírez-Bahena, M.H.; Santillana, N.; Zúñiga, D.; Álvarez-Martínez, E.R.; Peix, A.: Mhamdi, R.; Velázquez, E. Rhizobium laguerreae sp. nov. nodulates Vicia faba on several continents. Int. J. Syst. Evol. Microbiol. 2014, 64, 242-247.

223. Sánchez-Cañizares, C.; Rey, L.; Durán, D.; Temprano, F.; Sánchez-Jiménez, P.; Navarro, A.; Polajnar, M.; Imperial, J.; Ruiz-Argüeso, T. Endosymbiotic bacteria nodulating a new endemic lupine Lupinus mariae-josephi from alkaline soils in Eastern Spain represent a new lineage within the Bradyrhizobium genus. Syst. Appl. Microbiol. 2011, 34, 207-215.

224. Sankhla, I.S.; Tak, N.; Meghwal, R.R.; Choudhary, S.; Tak, A.; Rathi, S.; Sprent, J.I.; James, E.K.; Gehlot, H.S. Molecular characterization of nitrogen fixing microsymbionts from root nodules of Vachellia (Acacia) jacquemontii, a native legume from the Thar Desert of India. Plant Soil 2016, doi 10.1007/s11104-016-2838-9

225. Sannazzaro, A.I.; Bergottini, V.M.; Paz, R.C.; Castagno, L.N.; Menéndez, A.B.; Ruiz, O.A.; Pieckenstain, F.L.; Estrella, M.J. Comparative symbiotic performance of native rhizobia of the Flooding Pampa and 
strains currently used for inoculating Lotus tenuis in this region. Antonie van Leeuwenhoek, 2011, 99, 371-379.

226. Santillana, N.; Ramírez-Bahena, M.H.; García-Fraile, P.; Velázquez, E.; Zúñiga, D. Phylogenetic diversity based on $r r s, a t p D, r e c A$ genes and 16S-23S intergenic sequence analyses of rhizobial strains isolated from Vicia faba and Pisum sativum in Peru. Arch. Microbiol. 2008, 189, 239-247.

227. Sarr, P.S.; Araki, S.; Begoude, D.A.; Yemefack, M.; Manga, G.A.; Yamakawa, T.; Htwe, A.Z. Phylogeny and nitrogen fixation potential of Bradyrhizobium species isolated from the legume cover crop Pueraria phaseoloides (Roxb.) Benth. in Eastern Cameroon. Soil Sci. Plant Nutr. 2016, 62, 13-19.

228. Schwarz, E.N.; Ruhlman, T.A.; Sabir, J.S.M.; Hajirah, N.H.; Alharbi, N.S.; Al-Malki, A.L.; Bailey, C.D.; Jansen, R.K. Plastid genome sequences of legumes reveal parallel inversions and multiple losses of $r p s 16$ in papilionoids. J. System. Evol. 2015, 53, 458-468.

229. Shiraishi, A.; Matsushita, N.; Hougetsu, T. Nodulation in black locust by the Gammaproteobacteria Pseudomonas sp. and the Betaproteobacteria Burkholderia sp. Syst. Appl. Microbiol. 2010, 33, 269-274.

230. Silva, F.V.; de Meyer, S.E.; Simões-Araújo, J.L.; Barbé, T.daC.; Xavier, G.R.; O’Hara, G.; Ardley, J.K.; Rumjanek, N.G.; Willems, A.; Zilli, J.E. Bradyrhizobium manausense sp. nov., isolated from effective nodules of Vigna unguiculata grown in Brazilian Amazonian rainforest soils. Int. J. Syst. Evol. Microbiol. 2014, 64, 2358-2363.

231. Sinsuwongwat, S.; Nuntagij, A.; Shutsrirung, A.; Nomura, M.; Tajima, S. Characterization of local rhizobia in Thailand and distribution of malic enzymes. Soil Sci. Plant Nutr. 2002, 48, 719-727.

232. Sprent, J.I. Legume Nodulation A Global Perspective. Wiley-Blackwell: Chichester, UK, 2009.

233. Squartini, A.; Struffi, P.; Döring, H.; Selenska-Pobell, S.; Tola, E.; Giacomini, A.; Vendramin, E.; Velázquez, E.; Mateos, P.F.; Martinez-Molina, E.; Dazzo, F.B.; Casella, S.; Nuti, M.P. Rhizobium sullae sp. nov. (formerly 'Rhizobium hedysari'), the root-nodule microsymbiont of Hedysarum coronarium L. Int. J. Syst. Evol. Microbiol. 2002, 52, 1267-1276.

234. Steenkamp, E.T.; Stępkowski, T.; Przymusiak, A.; Botha, W.J.; Law, I.J. Cowpea and peanut in southern Africa are nodulated by diverse Bradyrhizobium strains harboring nodulation genes that belong to the large pantropical clade common in Africa. Mol. Phylogenet. Evol. 2008, 48, 1131-1144.

235. Stepkowski, T.; Moulin, L.; Krzyżańska, A.; McInnes, A.; Law, I.J.; Howieson, J. European origin of Bradyrhizobium populations infecting lupins and serradella in soils of Western Australia and South Africa. Appl. Environ. Microbiol. 2005, 71, 7041-7052.

236. Stępkowski, T.; Żak, M.; Moulin, L.; Króliczak, J.; Golińska, B.; Narożna, D.; Safronova, V.I.; Mądrzak, C.J. Bradyrhizobium canariense and Bradyrhizobium japonicum are the two dominant rhizobium species in root nodules of lupin and serradella plants growing in Europe. Syst. Appl. Microbiol. 2011, 34, 368-375.

237. Stroschein, M.R.D.; Eltz, F.L.F.; Antoniolli, Z.I.; Lupatini, M.; Vargas, L.K.; Giongo, A.; Pontelli, M.P. Symbiotic efficiency and genetic characteristics of Bradyrhizobium sp. strain UFSM LA 1.3 isolated from Lupinus albescens (H. et Arn). Sci. Agric. 2010, 67, 702-706.

238. Suominen, L.; Luukkainen, R.; Roos, C.; Lindström, K. Activation of the nodA promoter by the nodD genes of Rhizobium galegae induced by synthetic flavonoids or Galega orientalis root exudate. FEMS Microbiol. Lett. 2003, 219, 225-232.

239. Sy, A.; Giraud, E.; Jourand, P.; Garcia, N.; Willems, A.; de Lajudie, P.; Prin, Y.; Neyra, M.; Gillis, M.; Boivin-Masson, C.; Dreyfus, B. Methylotrophic Methylobacterium bacteria nodulate and fix nitrogen in symbiosis with legumes. J. Bacteriol. 2001, 183, 214-220.

240. Talbi, C.; Delgado, M.J.; Girard, L.; Ramirez-Trujillo, A.; Caballero-Mellado, J.; Bedmar, E.J. Burkholderia phymatum strains capable of nodulating Phaseolus vulgaris are present in Moroccan soils. Appl. Environ. Microbiol. 2010, 76, 4587-4591.

241. Tan, H.W.; Heenan, P.B.; De Meyer, S.E.; Willems, A.; Andrews, M. Diverse novel mesorhizobia nodulate New Zealand native Sophora species. Syst. Appl. Microbiol. 2015, 38, 91-98.

242. Tan, H.W.; Heenan, P.; Ridgway, H.; Andrews, M. The New Zealand alpine endemic Montigena novae-zelandiae (Fabaceae) shares rhizobial symbionts with Carmichaelia and Clianthus. New Zeal. J. Bot. 2013, 51, 297-307.

243. Tan, H.W.; Weir, B.S.; Carter, N.; Heenan, P.B.; Ridgway, H.J.; James, E.K.; Sprent, J.I.; Young, J.P.Y.; Andrews, M. Rhizobia with 16S rRNA and nifH similar to Mesorhizobium huakuii but novel recA, gln11, nodA and nodC genes are symbionts of New Zealand Carmichaelinae. PLoS ONE 2012, 7 (10), e47677. 
244. Tan, Z.Y.; Kan, F.L.; Peng, G.X.; Wang, E.T.; Reinhold-Hurek, B.; Chen, W.X. Rhizobium yanglingense sp. nov., isolated from arid and semi-arid regions in China. Int. J. Syst. Evol. Microbiol. 2001, 51, 909-914.

245. Tan, Z.Y.; Wang, E.T.; Peng, G.X.; Zhu, M.E.; Martínez-Romero, E.; Chen, W.X. Characterization of bacteria isolated from wild legumes in the north-western regions of China. Int. J. Syst. Bacteriol. 1999, 49, 1457-1469.

246. Tang, J.; Bromfield, E.S.P.; Rodrigue, N.; Cloutier, S.; Tambong, J.T. Microevolution of symbiotic Bradyrhizobium populations associated with soybeans in east North America. Ecol. Evol. 2012, 2, 2943-2961.

247. Taulé, C.; Zabaleta, M.; Mareque, C.; Platero, R.; Sanjurjo, L.; Sicardi, M.; Frioni, L.; Battistoni, F.; Fabiano, E. New Betaproteobacterial Rhizobium strains able to efficiently nodulate Parapiptadenia rigida (Benth.) Brenan. Appl. Environ. Microbiol. 2012, 78, 1692-1700.

248. Taurian, T.; Ibañez, F.; Fabra, A.; Aguilar, O.M. Genetic diversity of rhizobia nodulating Arachis hypogaea L. in Central Argentinean soils. Plant Soil 2006, 282, 41-52.

249. Tian, C.F.; Wang, E.T.; Wu, L.J.; Han, T.X.; Chen, W.F.; Gu, C.T.; Gu, J.G.; Chen, W.X. Rhizobium fabae sp. nov., a bacterium that nodulates Vicia faba. Int. J. Syst. Evol. Microbiol. 2008, 58, 2871-2875.

250. Tlusty, B.; van Berkum, P.; Graham, P.H. Characteristics of the rhizobia associated with Dalea spp. in the Ordway, Kellogg-Weaver Dunes, and Hayden prairies. Can. J. Microbiol. 2005, 51, 15-23.

251. Toledo, I.; Lloret, L.; Martinez-Romero, E. Sinorhizobium americanus sp. nov., a new Sinorhizobium species nodulating native Acacia spp. in Mexico. Syst. Appl. Microbiol. 2003, 26, 54-64.

252. Trujillo, M.E.; Willems, A.; Abril, A.; Planchuelo, A-M.; Rivas, R.; Ludeña, D.; Mateos, P.F.; Martínez-Molina, E.; Velázquez, E. Nodulation of Lupinus albus by strains of Ochrobactrum lupini sp. nov. Appl. Environ. Microbiol. 2005, 71, 1318-1327.

253. Ulrich, A.; Zaspel, I. Phylogenetic diversity of rhizobial strains nodulating Robinia pseudoacacia L. Microbiol. 2000, 146, 2997-3005.

254. Urtz, B.E.; Elkan, G.H. Genetic diversity among Bradyrhizobium isolates that effectively nodulate peanut (Arachis hypogaea). Can. J. Microbiol. 1996, 42, 1121-1130.

255. Valverde, A.; Igual, J.M.; Peix, A.; Cervantes, E.; Velázquez, E. Rhizobium lusitanum sp. nov. a bacterium that nodulates Phaseolus vulgaris. Int. J. System. Evol. Microbiol. 2006, 56, 2631-2637.

256. Valverde, A.; Velázquez, E.; Fernández-Santos, F.; Vizcaíno, N.; Rivas, R.; Mateos, P.F.; Martínez-Molina, E.; Igual, J.M.; Willems, A. Phyllobacterium trifolii sp. nov., nodulating Trifolium and Lupinus in Spanish soils. Int. J. System. Evol. Microbiol. 2005, 55, 1985-1989.

257. van Berkum, P.; Eardly, B.D. The aquatic budding bacterium Blastobacter denitrificans is a nitrogen-fixing symbiont of Aeschynomene indica. Appl. Environ. Microbiol. 2002, 68, 1132-1136.

258. van Berkum, P.; Beyene, D.; Bao, G.; Campbell, T.A.; Eardly, B.D. Rhizobium mongolense sp. nov. is one of three rhizobial genotypes identified which nodulate and form nitrogen-fixing symbioses with Medicago ruthenica [(L.) Ledebour]. Int. J. Syst. Bacteriol. 1998, 48, 13-22.

259. Velázquez, E.; Igual, J.M.; Willems, A.; Fernández, M.P.; Muñoz, E.; Mateos, P.F.; Abril, A.; Toro, N.; Normand, P.; Cervantes, E.; Gillis, M.; Martínez-Molina, E. Mesorhizobium chacoense sp. nov., a novel species that nodulates Prosopis alba in the Chaco Arido region (Argentina). Int. J. System. Evol. Microbiol. 2001, 51, 1011-1021.

260. Velázquez, E.; Valverde, A.; Rivas, R.; Gomis, V.; Peix, A.; Gantois, I.; Igual, J.M.; León-Barrios, M.; Willems, A.; Mateos, P.F.; Martínez-Molina, E. Strains nodulating Lupinus albus on different contintents belong to several new chromosomal and symbiotic lineages within Bradyrhizobium. Antonie van Leeuwenhoek. 2010, 97, 363-376.

261. Villegas, M.delC.; Rome, S.; Mauré, L.; Domergue, O.; Gardan, L.; Bailly, X.; Cleyet-Marel, J-C.; Brunel, B. Nitrogen-fixing sinorhizobia with Medicago laciniata constitute a novel biovar (bv. medicaginis) of S. meliloti. Syst. Appl. Microbiol. 2006, 29, 526-538.

262. Vinuesa, P.; Léon-Barrios, M.; Silva, C.; Willems, A.; Jarabo-Lorenzo, A.; Pérez-Galdona, R.; Werner, D.; Martínez-Romero, E. Bradyrhizobium canariense sp. nov., an acid-tolerant endosymbiont that nodulates endemic genistoid legumes (Papilionoideae: Genisteae) from the Canary Islands, along with Bradyrhizobium japonicum bv. genistearum, Bradyrhizobium genospecies alpha and Bradyrhizobium genospecies beta. Int. J. Syst. Evol. Microbiol. 2005a, 55, 569-575.

263. Vinuesa, P.; Rademaker, J.L.W.; de Bruijn, F.J.; Werner, D. Genotypic characterization of Bradyrhizobium strains nodulating endemic woody legumes of the Canary Islands by PCR-restriction fragment length 
polymorphism analysis of genes encoding $16 \mathrm{~S}$ rRNA (16S rDNA) and 16S-23S rDNA intergenic spacers, repetitive extragenic palindromic PCR genomic fingerprinting, and partial 16S rDNA sequencing. Appl. Environ. Microbiol. 1998, 64, 2096-2104.

264. Vinuesa, P.; Silva, C.; Lorite, M.J.; Izaguirre-Mayoral, M.L.; Bedmar, E.J.; Martínez-Romero, E. Molecular systematics of rhizobia based on maximum likelihood and Bayesian phylogenies inferred from rrs, atpD, recA and nifH sequences, and their use in the classification of Sesbania microsymbionts from Venezuelan wetlands. Syst. Appl. Microbiol. 2005b, 28, 702-716.

265. Vitousek, P.M.; Menge, D.N.L.; Reed, S.C.; Cleveland, C.C. Biological nitrogen fixation: rates, patterns and ecological controls in terrestrial ecosystems. Philos. T. Roy. Soc. B 2013, 368, 20130119

266. Wang, E.T.; Martínez-Romero, J.; Martínez-Romero, E. Genetic diversity of rhizobia from Leucaena leucocephala nodules in Mexican soils. Mol. Ecol. 1999a, 8, 711-724.

267. Wang, E.T.; van Berkum, P.; Sui, X.H.; Beyene, D.; Chen, W.X.; Martínez-Romero, E. Diversity of rhizobia associated with Amorpha fruticosa isolated from Chinese soils and description of Mesorhizobium amorphae sp. nov. Int. J. Syst. Bacteriol. 1999b, 49, 51-65.

268. Wang, E.T.; van Berkum, P.; Beyene, D.; Sui, X.H.; Dorado, O.; Chen, W.X.; Martínez-Romero, E. Rhizobium huautlense sp. nov., a symbiont of Sesbania herbacea that has a close phylogenetic relationship with Rhizobium galegae. Int. J. Syst. Bacteriol. 1998, 48, 687-699.

269. Wang, F.; Wang, E.T.; Wu, L.J.; Sui, X.H.; Li, Y.Jr.; Chen, W.X. Rhizobium vallis sp. nov., isolated from nodules of three leguminous species. Int. J. Syst. Evol. Microbiol. 2011, 61, 2582-2588.

270. Wang, H.; Man, C.X.; Wang, E.T.; Chen, W.X. Diversity of rhizobia and interactions among the host legumes and rhizobial genotypes in an agricultural-forestry ecosystem. Plant Soil 2009, 314, 169-182.

271. Wang, Y.C.; Wang, F.; Hou, B.C.; Wang, E.T.; Chen, W.F.; Sui, X.H.; Chen, W.X.; Li, Y.; Zhang, Y.B. Proposal of Ensifer psoraleae sp. nov., Ensifer sesbaniae sp. nov., Ensifer morelense comb. nov. and Ensifer americanum comb. nov. Syst. Appl. Microbiol. 2013a, 36, 467-473.

272. Wang, R.; Chang, Y.L.; Zheng, W.T.; Zhang, D.; Zhang, X.X.; Sui, X.H.; Wang, E.T.; Hu, J.Q.; Zhang, L.Y.; Chen, W.X. Bradyrhizobium arachidis sp. nov., isolated from effective nodules of Arachis hypogaea grown in China. Syst. Appl. Microbiol. 2013b, 36, 101-105.

273. Wang, J.Y.; Wang, R.; Zhang, Y.M.; Liu, H.C.; Chen, W.F.; Wang, E.T.; Sui, X.H.; Chen, W.X. Bradyrhizobium daqingense sp. nov., isolated from soybean nodules. Int. J. Syst. Evol. Microbiol. 2013c, 63, 616-624.

274. Wang, L.; Cao, Y.; Wang, E.T.; Qiao, Y.J.; Jiao, S.; Liu, Z.S.; Zhao, L.; Wei, G.H. Biodiversity and biogeography of rhizobia associated with common bean (Phaseolus vulgaris L.) in Shaanxi Province. Syst. Appl. Microbiol. 2016, 39, 211-219.

275. Wei G.; Chen, W.; Young, J.P.W.; Bontemps, C. A new clade of Mesorhizobium nodulating Alhagi sparsifolia. Syst. Appl. Microbiol. 2009, 32, 8-16.

276. Wei, G.H.; Yang, X-Y.; Zhang, Z-X.; Yang, Y-Z.; Lindström, K. Strain Mesorhizobium sp. CCNWGX035: a stress-tolerant isolate from Glycyrrhiza glabra displaying a wide host range of nodulation. Pedosphere 2008a, 18, 102-112.

277. Wei, G.H.; Zhang, Z.X.; Chen, C.; Chen, W.M.; Ju, W.T. Phenotypic and genetic diversity of rhizobia isolated from nodules of the legume genera Astragalus, Lespedeza and Hedysarum in northwestern China. Microbial. Res. 2008b, 163, 651-662.

278. Wojciechowski, M.F.; Lavin, M.; Sanderson, M.J. A phylogeny of legumes (Leguminosae) based on analysis of the plastid MATK gene resolves many well-supported subclades withing the family. Amer. J. Bot. 2004, 91, 1846-1862.

279. Wu, L.J.; Wang, H.Q.; Wang, E.T.; Chen, W.X.; Tian, C.F. Genetic diversity of nodulating and non-nodulating rhizobia associated with wild soybean (Glycine soja Sieb. \& Zucc.) in different ecoregions of China. FEMS Microbiol. Ecol. 2011, 76, 439-450.

280. Xu, K.W.; Penttinen, P.; Chen, Y.X.; Chen, Q.; Zhang, X. Symbiotic efficiency and phylogeny of the rhizobia isolated from Leucaena leucocephala in arid-hot river valley area in Panxi, Sichuan, China. Appl. Microbiol. Biotchnol. 2013, 97, 783-793.

281. Xu, K.W.; Zou, L.; Penttinen, P.; Wang, K.p; Heng, N.N.; Zhang, X.P.; Chen, Q.; Zhao, K.; Chen, Y.X. Symbiotic effectiveness and phylogeny of rhizobia isolated from faba bean (Vicia faba L.) in Sichuan hilly areas, China. Syst. Appl. Microbiol. 2015, 38, 515-523. 
282. Xu, K.W.; Zou, L.; Penttinen, P.; Zeng, X.; Liu, M.; Zhao, K.; Chen, C.; Chen, Y.X.; Zhang, X. Diversity and phylogeny of rhizobia associated with Desmodium spp. in Panxi, Sichuan, China. Syst. Appl. Microbiol. 2016, 39, 33-40.

283. Xu, L.M.; Ge, C.; Cui, Z.; Li, J.; Fan, H. Bradyrhizobium liaoningense sp. nov., isolated from the root nodules of soybeans. Int. J. Syst. Bacteriol. 1995, 45, 706-711.

284. Xu, L.; Shi, J.F.; Zhao, P.; Chen, W.M.; Qin, W.; Tang, M.; Wei, G.H. Rhizobium sphaerophysae sp. nov., a novel species isolated from root nodules of Sphaerophysa salsula in China. Antonie van Leeuwenhoek. 2011, 99, 845-854.

285. www.tropicalforages.info

286. Yan, A.M.; Wang, E.T.; Kan, F.L.; Tan, Z.Y.; Sui, X.H.; Reinhold-Hurek, B.; Chen, W.X. Sinorhizobium meliloti associated with Medicago sativa and Melilotus spp. in arid saline soils in Xinjiang, China. Int. J. Syst. Evol. Microbiol. 2000, 50, 1887-1891.

287. Yan, H.; Ji, Z.J.; Jiao, Y.S.; Wang, E.T.; Chen, W.F.; Guo, B.L.; Chen, W.X. Genetic diversity and distribution of rhizobia associated with the medicinal legumes Astragalus spp. and Hedysarum polybotrys in agricultural soils. Syst. Appl. Microbiol. 2016, 39, 141-149.

288. Yang, J.K.; Xie, F.L.; Zou, J.; Zhou, Q.; Zhou, J.C. Polyphasic characteristics of bradyrhizobia isolated from nodules of peanut (Arachis hypogaea) in China. Soil Biol. Biochem. 2005, 37, 141-153.

289. Yang, W.; Kong, Z.; Chen, W. Wei, G. Genetic diversity and symbiotic evolution of rhizobia from root nodules of Coronilla varia. Syst. Appl. Microbiol. 2013, 36, 49-55.

290. Yao, Y.; Wang, R.; Lu, J.K.; Sui, X.H.; Wang, E.T.; Chen, W.X. Genetic diversity and evolution of Bradyrhizobium populations nodulating Erythrophleum fordii, an evergreen tree indigenous to the southern subtropical region of China. Appl. Environ. Microbiol. 2014, 80, 6184-6194.

291. Yao, Z.Y.; Kan, F.L.; Wang, E.T.; Wei, G.H.; Chen, W.X. Characterization of rhizobia that nodulate legume species of the genus Lespedeza and description of Bradyrhizobium yuanmingense sp. nov. Int. J. Syst. Evol. Microbiol. 2002, 52, 2219-2230.

292. Yates, R.J.; Howieson, J.G.; Reeve, W.G.; Nandasena, K.G.; Law, I.J.; Bräu, L.; Ardley, J.K.; Nistelberger, H.M.; Real, D.; O'Hara, G.W. Lotononis angolensis forms nitrogen fixing, lupinoid nodules with phylogenetically unique, fast growing, pink-pigmented bacteria, which do not nodulate L. bainesii or $L$. listii. Soil Biol. Biochem. 2007, 39, 1680-1688.

293. Youseif, S.H.; Abd El-Megeed, F.H.; Ageez, A.; Cocking, E.C. Saleh, S.A. Phylogenetic multilocus sequence analysis of native rhizobia nodulating faba bean (Vicia faba L.) in Egypt. Syst. Appl. Microbiol. 2014, 37, 560-569.

294. Zahran, H.H.; Chahboune, R.; Moreno, S.; Bedmar, E.J.; Abdel-Fattah, M.; Yasser, M.M.; Mahmoud, A.M. Identification of rhizobial strains nodulating Egyptian grain legumes. Int. Microbiol. 2013, 16, 157-163.

295. Zhang, J.; Yang, X.; Guo, C.; de Lajudie, P.; Singh, R.P.; Wang, E.; Chen, W. Mesorhizobium muleiense and Mesorhizobium gsp. Nov. are symbionts of Cicer arietinum L. in alkaline soils of Gansu, Northwest China. Plant Soil 2016, doi: 10.1007/s11104-016-2987-x.

296. Zhang, J.J.; Jing, X.Y.; de Lajudie, P.; Ma, C.; He, P.X.; Singh, R.P.; Chen, W.F.; Wang, E.T. Association of white clover (Trifolium repens L.) with rhizobia of sv. trifolii belonging to three genomic species in alkaline soils in North and East China. Plant Soil 2016, doi 10.1007/s11104-016-2899-9.

297. Zhang, J.J.; Lou, K.; Jin, X.; Mao, P.H.; Wang, E.T.; Tian, C.F.; Sui, X.H.; Chen, W.F.; Chen, W.X. Distinctive Mesorhizobium populations associated with Cicer arietinum L. in alkaline soils of Xinjiang, China. Plant Soil. 2012, 353, 123-134.

298. Zhang, Y.F.; Wang, E.T.; Tian, C.F.; Wang, F.Q.; Han, L.L.; Chen, W.F.; Chen, W.X. Bradyrhizobium elkanii, Bradyrhizobium yuanmingense and Bradyrhizobium japonicum are the main rhizobia associated with Vigna unguiculata and Vigna radiata in the subtropical region of China. FEMS Microbiol. Lett. 2008, 285, 146-154.

299. Zhang, Y.M.; Li, Y.Jr.; Chen, W.F.; Wang, E.T.; Tian, C.F.; Li, Q.Q.; Zhang, Y.Z.; Sui, X.H.; Chen, W.X. Biodiversity and biogeography of rhizobia associated with soybean plants grown in the North China Plain. Appl. Environ. Microbiol. 2011, 77, 6331-6342.

300. Zhang, Y.J.; Zheng, W.T.; Everall, I.; Young, J.P.W.; Zhang, X.X.; Tian, C.F.; Sui, X.H.; Wang, E.T.; Chen, W.X.; Rhizobium anhuiense sp. nov., isolated from effective nodules of Vicia faba and Pisum sativum. Int. J. Syst. Evol. Microbiol. 2015, 65, 2960-2967. 
301. Zhao, C.T.; Wang, E.T.; Zhang, Y.M.; Chen, W.F.; Sui, X.H.; Chen, W.X.; Liu, H.C.; Zhang, X.X. Mesorhizobium silamurunense sp. nov., isolated from root nodules of Astragalus species. Int. J. Syst. Evol. Microbiol. 2012, 62, 2180-2186.

302. Zhao, L.; Deng, Z.; Yang, W.; Cao, Y.; Wang, E.; Wei, G. Diverse rhizobia associated with Sophora alopecuroides grown in different regions of Loess Plateau in China. Syst. Appl. Microbiol. 2010, 33, 468-477.

303. Zhao, L.; Fan, M.; Zhang, D.; Yang, R.; Zhang, F.; Xu, L.; Wei, X.; Shen, Y.; Wei, G. Distribution and diversity of rhizobia associated with wild soybean (Glycine soja Sieb. \& Zucc.) in Northwest China. Syst. Appl. Microbiol. 2014, 37, 449-456.

304. Zhao, L.; Wang, X.; Huo, H.; Yuan, G.; Sun, Y.; Zhang, D.; Cao, Y.; Xu, L.; Wei, G. Phylogenetic diversity of Ammopiptanthus rhizobia and distribution of rhizobia associated with Ammopiptanthus mongolicus in diverse regions of Northwest China. Microb. Ecol. 2016, doi 10.1007/s00248-016-0759-z

305. Zilli, J.E.; Baraúna, A.C.; da Silva, K.; De Meyer, S.E.; Farias, E.N.C.; Kaminski, P.E.; da Costa, I.B.; Ardley, J.K.; Willems, A.; Camacho, N.N.; Dourado, F.dosS.; O'Hara, G. Bradyrhizobium neotropicale sp. nov., isolate from effective nodules of Centrolobium paraense. Int. J. Syst. Evol. Microbiol. 2014, 64, 3950-3957.

Table 1. Legume-rhizobia symbioses in the legume sub-family Mimosoideae. All species have indeterminate nodules.

\begin{tabular}{|c|c|}
\hline $\begin{array}{l}\text { Mimosoideae } \\
\text { Tribes and genera }\end{array}$ & Rhizobia - field \\
\hline \multicolumn{2}{|l|}{ Ingeae } \\
\hline Acacia auriculiformis & $\begin{array}{l}\text { Bradyrhizobium [Manassila et al. 2007; Le Roux et } \\
\text { al. 2009; Helene et al. 2015] }\end{array}$ \\
\hline Acacia mangium & $\begin{array}{l}\text { Bradyrhizobium [Sinsuwongwat et al. 2002; Ngom } \\
\text { et al. 2004; Manassila et al. 2007; Le Roux et al. } \\
\text { 2009], Ochrobactrum [Ngom et al. 2004], Rhizobium } \\
\text { [Ngom et al. 2004] }\end{array}$ \\
\hline Acacia mangium $\times$ A. auriculiformis & Bradyrhizobium [Le Roux et al. 2009] \\
\hline Acacia mearnsii & Ensifer [Lortet et al. 1996; Räsänen et al. 2001] \\
\hline Acacia melanoxylon & Bradyrhizobium [Lu et al. 2014] \\
\hline Acacia saligna & $\begin{array}{l}\text { Bradyrhizobium [Marsudi et al. 1999; Helene et al. } \\
\text { 2015], Ensifer [Khbaya et al. 1998], Rhizobium } \\
\text { [Marsudi et al. 1999] }\end{array}$ \\
\hline Acaciella angustissima & $\begin{array}{l}\text { Ensifer [Lloret et al. 2007; Rincon-Rosales et al. } \\
\text { 2009] }\end{array}$ \\
\hline Calliandra calothyrsis & $\begin{array}{l}\text { Ensifer [Bala \& Giller, 2001], Rhizobium [Bala \& } \\
\text { Giller, 2001] }\end{array}$ \\
\hline Calliandra grandiflora & $\begin{array}{l}\text { Ensifer [Rincón-Rosales et al. 2013], Mesorhizobium } \\
\text { [Rincón-Rosales et al. 2013], Rhizobium } \\
\text { [Rincón-Rosales et al. 2013] }\end{array}$ \\
\hline Faidherbia albida & Bradyrhizobium [Odee et al. 2002] \\
\hline Inga edulis & Bradyrhizobium [Leblanc et al. 2005] \\
\hline Inga laurina & Bradyrhizobium [da Silva et al. 2014] \\
\hline Mariosousa acatlensis & Ensifer [Toledo et al. 2003] \\
\hline Senegalia laeta & Ensifer [Lortet et al. 1996] \\
\hline Senegalia macilenta & Ensifer [Toledo et al. 2003], \\
\hline Senegalia senegal & $\begin{array}{l}\text { Ensifer [Lortet et al. 1996; Räsänen et al. 2001], } \\
\text { Rhizobium [Lortet et al. 1996; Fall et al. 2008], } \\
\text { Mesorhizobium [Fall et al. 2008] }\end{array}$ \\
\hline \multicolumn{2}{|l|}{ Mimoseae } \\
\hline Anadenanthera peregrina & Burkholderia [Bournaud et al. 2013] \\
\hline
\end{tabular}




\begin{tabular}{|c|c|}
\hline Desmanthus illinoensis & Rhizobium [Beyhaut et al. 2006] \\
\hline Desmanthus paspalaceus & $\begin{array}{l}\text { Mesorhizobium [Fornasero et al. 2014], Rhizobium } \\
\text { [Fornasero et al. 2014] }\end{array}$ \\
\hline Desmanthus virgatus & Rhizobium [Sinsuwongwat et al. 2002] \\
\hline Leucaena leucocephala & $\begin{array}{l}\text { Ensifer [Wang et al. 1999a; Bala \& Giller, 2001; Xu et } \\
\text { al. 2013], Mesorhizobium [Wang et al. 1999a; Bala \& } \\
\text { Giller, 2001; Xu et al. 2013], Rhizobium [Wang et al. } \\
\text { 1999a; Bala \& Giller, 2001; López-López et al. 2012] }\end{array}$ \\
\hline Microlobius foetidus & $\begin{array}{l}\text { Bradyrhizobium [Bournaud et al. 2013], Rhizobium } \\
\text { [Bournaud et al. 2013] }\end{array}$ \\
\hline 50 Mimosa spp. & $\begin{array}{l}\text { Burkholderia [Chen et al. 2003, 2005a,b; Barrett \& } \\
\text { Parker 2005, 2006; Liu et al. 2007; Parker et al. 2007; } \\
\text { Elliott et al. 2009; Bontemps et al. 2010; Liu et al. } \\
\text { 2011; Liu et al. 2012; Gehlot et al. 2013]. }\end{array}$ \\
\hline Mimosa affinis & Rhizobium [Elliot et al. 2009] \\
\hline Mimosa asperata & Cupriavidus [Andam et al. 2007] \\
\hline Mimosa borealis & Ensifer [Bontemps et al. 2016] \\
\hline Mimosa ceratonia & Rhizobium [Elliot et al. 2009] \\
\hline Mimosa cruenta & Cupriavidus [Platero et al. 2016] \\
\hline Mimosa diplotricha & $\begin{array}{l}\text { Cupriavidus [Chen et al. 2003, Liu et al. 2011; Liu et } \\
\text { al. 2012], Rhizobium [Chen et al. 2003; Elliott et al. } \\
\text { 2009] }\end{array}$ \\
\hline Mimosa hamata, Mimosa himalayana & Ensifer [Gehlot et al. 2013] \\
\hline Mimosa invisa & Rhizobium [Liu et al. 2007] \\
\hline Mimosa magnate & Cupriavidus [Platero et al. 2016] \\
\hline Mimosa pigra & $\begin{array}{l}\text { Cupriavidus [Chen et al. 2005b; Barrett \& Parker } \\
\text { 2006] }\end{array}$ \\
\hline Mimosa polyantha & Rhizobium [Bontemps et al. 2016] \\
\hline Mimosa pudica & $\begin{array}{l}\text { Bradyrhizobium [Liu et al. 2007], Cupriavidus [Chen } \\
\text { et al. 2003; Barrett \& Parker, 2006; Elliott et al. 2009; } \\
\text { Liu et al. 2011; Liu et al. 2012; Gehlot et al. 2013], } \\
\text { Rhizobium [Barrett \& Parker, 2006; Liu et al. 2007] }\end{array}$ \\
\hline Mimosa ramulosa, Mimosa reptans, Mimosa schleidenii & Cupriavidus [Platero et al. 2016] \\
\hline Mimosa strigillosa & Ensifer [Andam et al. 2007] \\
\hline Mimosa tequilana & Rhizobium [Bontemps et al. 2016] \\
\hline Neptunia natans & $\begin{array}{l}\text { Allorhizobium [de Lajudie 1998], Devosia [Rivas et } \\
\text { al. 2002] }\end{array}$ \\
\hline Parapiptadenia pterosperma & Burkholderia [Bournaud et al. 2013] \\
\hline Parapiptadenia rigida & $\begin{array}{l}\text { Burkholderia [Bournaud et al. 2013], Cupriavidus } \\
\text { [Taulé et al. 2012], Rhizobium [Bournaud et al. 2013] }\end{array}$ \\
\hline Piptadenia adiantoides, Piptadenia flava & Rhizobium [Bournaud et al. 2013] \\
\hline Piptadenia gonoacantha & $\begin{array}{l}\text { Burkholderia [Bournaud et al. 2013], Rhizobium } \\
\text { [Bournaud et al. 2013] }\end{array}$ \\
\hline Piptadenia paniculata & $\begin{array}{l}\text { Burkholderia [Bournaud et al. 2013], Rhizobium } \\
\text { [Bournaud et al. 2013] }\end{array}$ \\
\hline $\begin{array}{l}\text { Piptadenia stipulacea, Piptadenia trisperma, Piptadenia } \\
\text { vividiflora }\end{array}$ & Burkholderia [Bournaud et al. 2013] \\
\hline Prosopis alba & $\begin{array}{l}\text { Bradyrhizobium [Diaz et al. 2013], Ensifer [Iglesias } \\
\text { et al. 2007; Diaz et al. 2013], Mesorhizobium } \\
\text { [Velázquez et al. 2001; Diaz et al. 2013], Rhizobium } \\
\text { [Iglesias et al. 2007] }\end{array}$ \\
\hline Prosopis chilensis & Ensifer [Nick et al. 1999; Räsänen et al. 2001] \\
\hline
\end{tabular}




\begin{tabular}{|c|c|}
\hline Prosopis cineraria & Ensifer [Gehlot et al. 2012] \\
\hline Prosopis farcta & $\begin{array}{l}\text { Ensifer [Fterich et al. 2011], Mesorhizobium [Fterich } \\
\text { et al. 2011] }\end{array}$ \\
\hline Prosopis juliflora & $\begin{array}{l}\text { Achromobacter [Benata et al. 2008], Ensifer [Benata et } \\
\text { al. 2008], Rhizobium [Benata et al. 2008] }\end{array}$ \\
\hline Pseudopiptadenia contorta & Burkholderia [Bournaud et al. 2013] \\
\hline Stryphnodendron sp. & Bradyrhizobium [Bournaud et al. 2013] \\
\hline Vachellia abyssinica & $\begin{array}{l}\text { Mesorhizobium [Degefu et al. 2011], Ensifer [Degefu } \\
\text { et al. 2012] }\end{array}$ \\
\hline Vachellia cochliacantha, Vachellia farnesiana & Ensifer [Toledo et al. 2003] \\
\hline Vachellia gummifera & Ensifer [Khbaya et al. 1998] \\
\hline Vachellia horrida & Ensifer [Lortet et al. 1996; Khbaya et al. 1998] \\
\hline Vachellia jacquemontii & Ensifer [Gehlot et al. 2012; Sankhla et al. 2016] \\
\hline Vachellia macracantha & $\begin{array}{l}\text { Ensifer [Cordero et al. 2016], Rhizobium [Cordero et } \\
\text { al. 2016] }\end{array}$ \\
\hline Vachellia nubica & Bradyrhizobium [Odee et al. 2002] \\
\hline Vachellia seyal & $\begin{array}{l}\text { Rhizobium [Lortet et al. 1996], Ensifer [Degefu et al. } \\
\text { 2012] }\end{array}$ \\
\hline Vachellia pennatula & Ensifer [Toledo et al. 2003] \\
\hline Vachellia tortilis & $\begin{array}{l}\text { Ensifer [Lortet et al. 1996; Khbaya et al. 1998; Ba et } \\
\text { al. 2002; Degefu et al. 2012], Mesorhizobium [Lortet } \\
\text { et al. 1996; Ba et al. 2002; Odee et al. 2002; Degefu et } \\
\text { al. 2011], Rhizobium [Ba et al. 2002] }\end{array}$ \\
\hline Vachellia xanthophloea & Mesorhizobium [Odee et al. 2002] \\
\hline Xylia xylocarpa & $\begin{array}{l}\text { Bradyrhizobium [Sinsuwongwat et al. 2002; } \\
\text { Manasila et al. 2007] }\end{array}$ \\
\hline
\end{tabular}

Table 2. Legume-rhizobia symbioses in the inverted repeat lacking clade (IRLC) of the legume sub-family Papilionoideae. All species in the IRLC have indeterminate nodules.

\begin{tabular}{|c|c|}
\hline $\begin{array}{l}\text { Papilionoidieae } \\
\text { Tribes and genera }\end{array}$ & Rhizobia - field \\
\hline \multicolumn{2}{|l|}{ Cicereae } \\
\hline Cicer arietinum & $\begin{array}{l}\text { Mesorhizobium [Nour et al. 1994; Aouani et al. 2001; } \\
\text { Maâtallah et al. 2002; Rivas et al. 2007; Ben } \\
\text { Romdhane et al. 2009; Zhang et al. 2012; Zahran et } \\
\text { al. 2013; Zhang et al. 2016] }\end{array}$ \\
\hline Cicer canariense & Mesorhizobium [Armas-Capote et al. 2014] \\
\hline \multicolumn{2}{|l|}{ Fabeae } \\
\hline Lathyrus aphaca, Lathyrus nissolia, Lathyrus pratensis & Rhizobium [Mutch \& Young, 2004] \\
\hline Lathyrus japonicus & Rhizobium [Aoki et al. 2010] \\
\hline Lathyrus odoratus & Rhizobium [Han et al. 2008b] \\
\hline Lens culinaris & $\begin{array}{l}\text { Rhizobium [Rashid et al. 2012; Zahran et al. 2013; } \\
\text { Riah et al. 2014] }\end{array}$ \\
\hline Pisum sativum & $\begin{array}{l}\text { Rhizobium [Mutch \& Young, 2004; Zahran et al. } \\
\text { 2013; Riah et al. 2014; Zhang et al. 2015] }\end{array}$ \\
\hline Vicia amoena & Rhizobium [Kan et al. 2007] \\
\hline Vicia bungei & Rhizobium [Kan et al. 2007] \\
\hline Vicia cracca & $\begin{array}{l}\text { Rhizobium [Mutch \& Young, 2004; Kan et al. 2007; } \\
\text { Ampomah \& Huss-Danell, 2016] }\end{array}$ \\
\hline Vicia hirsuta & $\begin{array}{l}\text { Rhizobium [Mutch \& Young, 2004; Han et al. 2008b; } \\
\text { Ampomah \& Huss-Danell, 2016] }\end{array}$ \\
\hline Vicia faba & Rhizobium [Mutch \& Young, 2004; Kan et al. 2007; \\
\hline
\end{tabular}




\begin{tabular}{|c|c|}
\hline & $\begin{array}{l}\text { Santillana et al. 2008; Saidi et al. 2013; Zahran et al. } \\
\text { 2013; Youseif et al. 2014; Xu et al. 2015; Zhang et al. } \\
\text { 2015] }\end{array}$ \\
\hline Vicia multicaulis & Rhizobium [Ampomah \& Huss-Danell, 2016] \\
\hline Vicia sativa & $\begin{array}{l}\text { Rhizobium [Mutch \& Young, 2004; Kan et al. 2007; } \\
\text { Lei et al. 2008; Tian et al. 2008; Alvarez-Martinez et } \\
\text { al. 2009; Rejili et al. 2012] }\end{array}$ \\
\hline Vicia sepium & $\begin{array}{l}\text { Rhizobium [Kan et al. 2007; Ampomah \& } \\
\text { Huss-Danell, 2016] }\end{array}$ \\
\hline Vicia sylvatica & Rhizobium [Ampomah \& Huss-Danell, 2016] \\
\hline Vicia tetrasperma & Rhizobium [Ampomah \& Huss-Danell, 2016] \\
\hline Vicia villosa & Rhizobium [Kan et al. 2007] \\
\hline \multicolumn{2}{|l|}{ Galegeae } \\
\hline Astragalus adsurgense & $\begin{array}{l}\text { Ensifer [Chen et al. 2015], Mesorhizobium [Chen et } \\
\text { al. 2015], Rhizobium [Wei et al. 2008b] }\end{array}$ \\
\hline Astragalus aksuensis & Rhizobium [Han et al. 2008b] \\
\hline Astragalus betetovii & Rhizobium [Han et al. 2008b] \\
\hline Astragalus complanatus & $\begin{array}{l}\text { Ensifer [Chen et al. 2015], Mesorhizobium [Chen et } \\
\text { al. 2015], Rhizobium [Wei et al. 2008b] }\end{array}$ \\
\hline Astragalus chrysopterus & Rhizobium [Wei et al. 2008b] \\
\hline $\begin{array}{l}\text { Astragalus discolor, Astragalus efoliolatus, Astragalus } \\
\text { kifonsanicus }\end{array}$ & Mesorhizobium [Chen et al. 2015] \\
\hline Astragalus melilotoides & $\begin{array}{l}\text { Ensifer [Chen et al. 2015], Mesorhizobium [Chen et } \\
\text { al. 2015] }\end{array}$ \\
\hline Astragalus membranaceus & $\begin{array}{l}\text { Mesorhizobium [Zhao et al. 2012; Chen et al. 2015; } \\
\text { Yan et al. 2016] }\end{array}$ \\
\hline Astragalus mongholicus & Mesorhizobium [Yan et al. 2016] \\
\hline Astragalus polycladus & Rhizobium [Chen et al. 2015] \\
\hline Astragalus scaberrimus & $\begin{array}{l}\text { Mesorhizobium [Chen et al. 2015], Rhizobium [Wei et } \\
\text { al. 2008b] }\end{array}$ \\
\hline Biserrula pelecinus & $\begin{array}{l}\text { Mesorhizobium [Nandasena et al. 2001; Nandasena } \\
\text { et al. 2009] }\end{array}$ \\
\hline Carmichaelia australis, Carmichaelia monroi, & Mesorhizobium [Tan et al. 2012] \\
\hline Clianthus puniceus & Mesorhizobium [Tan et al. 2012] \\
\hline Colutea arborescens & $\begin{array}{l}\text { Ensifer [Ourarhi et al. 2011], Mesorhizobium } \\
\text { [Ruiz-Diéz et al. 2009; Ourarhi et al. 2011], } \\
\text { Rhizobium [Ourarhi et al. 2011] }\end{array}$ \\
\hline Galega officinalis & Neorhizobium [Radeva et al. 2001; Liu et al. 2012] \\
\hline Galega orientalis & Neorhizobium [Radeva et al. 2001] \\
\hline Glycyrrhiza eurycarpa & Ensifer [Li et al. 2012] \\
\hline Glycyrrhiza glabra & $\begin{array}{l}\text { Mesorhizobium [Wei et al. 2008a; Li et al. 2012], } \\
\text { Rhizobium [Li et al. 2012] }\end{array}$ \\
\hline Glycyrrhiza inflata & Ensifer [Li et al. 2012] \\
\hline Glycyrrhiza multiflora & Mesorhizobium [Tan et al. 1999] \\
\hline Glycyrrhiza pallidiflora & Mesorhizobium [Chen et al. 1995] \\
\hline Glycyrrhiza uralensis & $\begin{array}{l}\text { Mesorhizobium Tan et al. 1999; Li et al. 2012], } \\
\text { Rhizobium [Li et al. 2012] }\end{array}$ \\
\hline Glycyrrhiza sp. & Mesorhizobium [Li et al. 2012] \\
\hline Gueldenstaedtia multiflora & $\begin{array}{l}\text { Mesorhizobium [Tan et al. 1999], Rhizobium [Tan et } \\
\text { al. 1999; Tan et al. 2001] }\end{array}$ \\
\hline $\begin{array}{l}\text { Lessertia annulans, Lessertia capitata, Lessertia diffusa, } \\
\text { Lessertia excisa, Lessertia frutescens, Lessertia herbacea, }\end{array}$ & Mesorhizobium [Gerding et al. 2012] \\
\hline
\end{tabular}




\begin{tabular}{|c|c|}
\hline \multicolumn{2}{|l|}{ Lessertia microphylla, Lessertia pauciflora } \\
\hline Lessertia sp. & Ensifer [Lemaire et al. 2015] \\
\hline Montigena novae-zelandiae & Mesorhizobium [Tan et al. 2013] \\
\hline Oxytropis glabra & $\begin{array}{l}\text { Ensifer [Kan et al. 2007], Mesorhizobium [Han et al. } \\
\text { 2008a], Rhizobium [Kan et al. 2007; Han et al. 2008b] }\end{array}$ \\
\hline Oxytropis kansuenses & Rhizobium [Kan et al. 2007] \\
\hline Oxytropis meinshausenii & Rhizobium [Han et al. 2008b] \\
\hline Oxytropis myriophylla & Mesorhizobium [Kan et al. 2007] \\
\hline Oxytropis ochrocephala & $\begin{array}{l}\text { Mesorhizobium [Kan et al. 2007], Rhizobium [Kan et } \\
\text { al. 2007] }\end{array}$ \\
\hline Oxytropis psammocharis & Rhizobium [Kan et al. 2007] \\
\hline Oxytropis sp. & Phyllobacterium [Kan et al. 2007] \\
\hline Sphaerophysa salsula & $\begin{array}{l}\text { Ensifer [Deng et al. 2011], Mesorhizobium [Deng et } \\
\text { al. 2011], Rhizobium [Deng et al. 2011; Xu et al. } \\
\text { 2011] }\end{array}$ \\
\hline Swainsona leeana, Swainsona pterostylis & Ensifer [Yates et al. 2004] \\
\hline Swainsona galegifolia & Mesorhizobium [Tan et al. 2013] \\
\hline \multicolumn{2}{|l|}{ Hedysareae } \\
\hline Alhagi sparsifolia & Mesorhizobium [Wei et al. 2009] \\
\hline Alhagi toum & Rhizobium [Han et al 2008b] \\
\hline Caragana bicolor, Caragana erinacea & Mesorhizobium, Rhizobium [Lu et al. 2009] \\
\hline Caragana franchetiana & Mesorhizobium, [Lu et al. 2009] \\
\hline Caragana intermedia & $\begin{array}{l}\text { Bradyrhizobium [ Lu et al. 2009], Mesorhizobium [Tan } \\
\text { et al. 1999; Lu et al. 2009], Rhizobium [Lu et al. 2009] }\end{array}$ \\
\hline Caragana jubata & Rhizobium [Han et al. 2008b] \\
\hline Caragana microphylla & Mesorhizobium [Guan et al. 2008] \\
\hline Halimodendron halodendron & Rhizobium [Han et al 2008b] \\
\hline Hedysarum coronarium & Rhizobium [Squartini et al. 2002; Liu et al. 2012] \\
\hline Hedysarum polybotrys & $\begin{array}{l}\text { Rhizobium [Wei et al. 2008b], Mesorhizobium [Yan et } \\
\text { al. 2016] }\end{array}$ \\
\hline Hedysarum scoparium & Rhizobium [Wei et al. 2008b] \\
\hline Hedysarum spinosissimum & Ensifer [Rejilli et al. 2012] \\
\hline Onobrychis viciifolia & Phyllobacterium [Baimiev et al. 2007] \\
\hline \multicolumn{2}{|l|}{ Millettieae } \\
\hline Milletia leucantha & Bradyrhizobium [Manassila et al. 2007] \\
\hline Millettia pinnata & Rhizobium [Kesari et al. 2013] \\
\hline Tephrosia capensis & Bradyrhizobium [Lemaire et al. 2015] \\
\hline Tephrosia falciformis & $\begin{array}{l}\text { Bradyrhizobium [Gehlot et al. 2012], Ensifer [Gehlot } \\
\text { et al. 2012] }\end{array}$ \\
\hline Tephrosia purpurea & $\begin{array}{l}\text { Bradyrhizobium [Doignon-Bourcier et al. 1999], } \\
\text { Ensifer [Gehlot et al. 2012], Rhizobium [Gehlot et al. } \\
\text { 2012] }\end{array}$ \\
\hline Tephrosia villosa & $\begin{array}{l}\text { Bradyrhizobium [Doignon-Bourcier et al. 1999; } \\
\text { Gehlot et al. 2012], Ensifer [Gehlot et al. 2012] }\end{array}$ \\
\hline Tephrosia wallichii & Ensifer [Gehlot et al. 2012] \\
\hline \multicolumn{2}{|l|}{ Trifolieae } \\
\hline Medicago archiducis-nicolai & Rhizobium [Kan et al. 2007] \\
\hline Medicago intertexta & Ensifer [El Batanony et al. 2015] \\
\hline Medicago laciniata & $\begin{array}{l}\text { Ensifer [Villegas et al. 2006; Badri et al. 2007; Mnasri } \\
\text { et al. 2009; El Batonany et al. 2015], Neorhizobium } \\
\text { [El Batonany et al. 2015] }\end{array}$ \\
\hline Medicago lupulina & Ensifer [Kan et al. 2007; Wang et al. 2009] \\
\hline Medicago orbicularis & Ensifer [Rome et al. 1996] \\
\hline
\end{tabular}




\begin{tabular}{|l|l|}
\hline Medicago polymorpha & $\begin{array}{l}\text { Ensifer [El Batanony et al. 2015], Neorhizobium [El } \\
\text { Batonany et al. 2015] }\end{array}$ \\
\hline Medicago rigiduloides & Ensifer [Gubry-Rangin et al. 2013] \\
\hline Medicago ruthenica & Rhizobium [van Berkum et al. 1998] \\
\hline Medicago sativa & $\begin{array}{l}\text { Ensifer [Yan et al. 2000; Kan et al. 2007; Mnsasri et } \\
\text { al. 2009; Bromfield et al. 2010; Merabet et al. 2010; } \\
\text { Djedidi et al. 2011], Neorhizobium [El Batanony et al. } \\
\text { 2015], Rhizobium [Bromfield et al. 2010] }\end{array}$ \\
\hline Medicago scutellata & Ensifer [Mnasri et al. 2009] \\
\hline Medicago truncatula & $\begin{array}{l}\text { Ensifer [Rome et al. 1996; Badri et al. 2007; Mnasri } \\
\text { et al. 2009] }\end{array}$ \\
\hline Melilotus alba & $\begin{array}{l}\text { Ensifer [Bromfield et al. 2010], Rhizobium } \\
\text { [Bromfield et al. 2010] }\end{array}$ \\
\hline Melilotus indicus, Melilotus messanensis & Ensifer [El Batanony et al. 2015] \\
\hline Melilotus officinalis & Ensifer [Kan et al. 2007; Wang et al. 2009] \\
\hline Melilotus siculus & Ensifer [El Batanony et al. 2015] \\
\hline Trifolium fragiferum & $\begin{array}{l}\text { Bradyrhizobium [Liu et al. 2007], Mesorhizobium [Liu } \\
\text { et al. 2007], Rhizobium [Liu et al. 2007] }\end{array}$ \\
\hline Trifolium pratense & Phyllobacterium [Valverde et al. 2005], \\
\hline Trifolium repens & $\begin{array}{l}\text { Bradyrhizobium [Liu et al. 2007], Ensifer [Liu et al. } \\
\text { 2007], Rhizobium [Liu et al. 2007; Zhang et al. 2016] }\end{array}$ \\
\hline Trigonella maritima & Ensifer [Rejili et al. 2012; El Batanony et al. 2015] \\
\hline
\end{tabular}

Table 3. Legume-rhizobia symbioses of species in the sub-family Papilionoideae with indeterminate nodules excluding the inverted repeat lacking clade.

\begin{tabular}{|c|c|}
\hline $\begin{array}{l}\text { Papilionoideae } \\
\text { Tribes (genera) }\end{array}$ & Rhizobia - field \\
\hline \multicolumn{2}{|l|}{ Abreae } \\
\hline Abrus precatorius & Ensifer [Ogasawara et al. 2003] \\
\hline \multicolumn{2}{|l|}{ Amorpheae } \\
\hline Amorpha fruticosa & $\begin{array}{l}\text { Bradyrhizobium [Wang et al. 1999b], Mesorhizobium } \\
\text { [Tan et al. 1999; Wang et al. 1999b; Wang et al. } \\
\text { 2009] }\end{array}$ \\
\hline Dalea purpurea & $\begin{array}{l}\text { Mesorhizobium [Tlusty et al. 2005], Rhizobium } \\
\text { [Tlusty et al. 2005] }\end{array}$ \\
\hline \multicolumn{2}{|l|}{ Crotalarieae } \\
\hline Aspalathus callosa & Burkholderia [Lemaire et al. 2015] \\
\hline Aspalathus ciliaris, Aspalathus unifllora & Mesorhizobium [Lemaire et al. 2015] \\
\hline Aspalathus linearis & $\begin{array}{l}\text { Bradyrhizobium [Hassen et al. 2012], Burkholderia } \\
\text { [Hassen et al. 2012], Herbaspirillum [Hassen et al. } \\
\text { 2012], Mesorhizobium [Hassen et al. 2012], Rhizobium } \\
\text { [Hassen et al. 2012] }\end{array}$ \\
\hline $\begin{array}{l}\text { Crotalaria comosa, Crotalaria hyssopifolia, Crotalaria } \\
\text { lathyroides }\end{array}$ & Bradyrhizobium [Sy et al. 2001] \\
\hline Crotalaria pallida & $\begin{array}{l}\text { Bradyrhizobium [Liu et al. 2007], Burkholderia [Liu et } \\
\text { al. 2007], Rhizobium [Liu et al. 2007] }\end{array}$ \\
\hline Crotalaria perrotteti, Crotalaria podocarpa & Methylobacterium [Sy et al. 2001] \\
\hline Crotalaria sp. & Burkholderia [Lemaire et al. 2015] \\
\hline Lebeckia ambigua & Burkholderia [Howieson et al. 2013] \\
\hline Listia angolensis & Microvirga [Ardley et al. 2012] \\
\hline Listia bainesii, Listia solitudinis, Listia listii & Methylobacterium [Yates et al. 2007] \\
\hline Rafnia sp. & Burkholderia [Lemaire et al. 2015] \\
\hline
\end{tabular}




\begin{tabular}{|c|c|}
\hline Genisteae & \\
\hline Adenocarpus hispanicus & Phyllobacterium [Ruiz-Diéz et al. 2009] \\
\hline Argyrolobium uniflorum & Ensifer [Mnasri et al. 2009; Merabet et al. 2010] \\
\hline Argyrolobium sp. & Mesorhizobium [Lemaire et al. 2015] \\
\hline Cytisus aeolicus & Bradyrhizobium [Cardinale et al. 2008] \\
\hline Cytisus balansae & Bradyrhizobium [Rodriguez-Echeverria et al. 2003] \\
\hline Cytisus laburnum & Bradyrhizobium [Ruiz-Diez et al. 2009] \\
\hline Cytisus multiflorus & Bradyrhizobium [Rodriguez-Echeverria et al. 2003] \\
\hline Cytisus proliferus & $\begin{array}{l}\text { Bradyrhizobium [Vinuesa et al. 1998; Jarabo-Lorenzo } \\
\text { et al. 2000; Jarabo-Lorenzo et al 2003; Vinuesa et al. } \\
\text { 2005a] }\end{array}$ \\
\hline Cytisus purgans & Bradyrhizobium [Ruiz-Diez et al. 2009] \\
\hline Cytisus scoparius & Bradyrhizobium [Kalita et al. 2004; Horn et al. 2014] \\
\hline Cytisus striatus & Bradyrhizobium [Rodriguez-Echeverria et al. 2003] \\
\hline Cytisus villosus & Bradyrhizobium [Chahboune et al. 2011] \\
\hline Genista hystrix & Bradyrhizobium [Rodriguez-Echeverria, 2003] \\
\hline Genista stenopetula & Bradyrhizobium [Vinuesa et al. 2005a] \\
\hline Genista versicolor & Bradyrhizobium [Cobo-Diaz et al. 2014] \\
\hline Lupinus albescens & $\begin{array}{l}\text { Bradyrhizobium [Stroschein et al. 2010; Granada et } \\
\text { al. 2015] }\end{array}$ \\
\hline Lupinus albus & $\begin{array}{l}\text { Bradyrhizobium [ Jarabo-Lorenzo 2003, Velazquez et } \\
\text { al. 2010; Stepkowski et al. 2011] }\end{array}$ \\
\hline Lupinus angustifolius & $\begin{array}{l}\text { Bradyrhizobium [Jarabo-Lorenzo 2003; Stepkowski } \\
\text { et al. 2011] }\end{array}$ \\
\hline Lupinus honoratus & Ochrobactrum [Trujillo et al. 2005] \\
\hline Lupinus luteus & $\begin{array}{l}\text { Bradyrhizobium [Jarabo-Lorenzo et al. 2003; } \\
\text { Stepkowski et al. 2011] }\end{array}$ \\
\hline Lupinus mariae-josephae & $\begin{array}{l}\text { Bradyrhizobium [Sánchez-Cañizares et al. 2011; } \\
\text { Duran et al. 2013] }\end{array}$ \\
\hline Lupinus montanus & Bradyrhizobium [Vinuesa et al. 2005] \\
\hline Lupinus polyphyllus & $\begin{array}{l}\text { Bradyrhizobium [Vinuesa et al. 2005; Ryan-Salter et } \\
\text { al. 2014] }\end{array}$ \\
\hline Lupinus texensis & Microvirga [Ardley et al. 2012] \\
\hline Lupinus sp. & Bradyrhizobium [Jarabo-Lorenzo et al. 2003] \\
\hline Retama monosperma & Bradyrhizobium [Guerrouj et al. 2013] \\
\hline Retama raetam & Bradyrhizobium [Farida et al. 2009] \\
\hline Retama sphaerocarpa & $\begin{array}{l}\text { Bradyrhizobium [Rodriguez-Echeverria, 2003; } \\
\text { Farida et al. 2009; Guerrouj et al. 2013; Rodriguez } \\
\text {-Echeverria, 2014], Phyllobacterium [Ruiz-Diez et al. } \\
\text { 2009] }\end{array}$ \\
\hline Spartium junceum & $\begin{array}{l}\text { Bradyrhizobium [Quatrini et al. 2002; Cardinale et al. } \\
\text { 2008; Ruiz-Diéz et al. 2009], Phyllobacterium } \\
\text { [Ruiz-Diez et al. 2009] }\end{array}$ \\
\hline Ulex europaeus & Bradyrhizobium [Liu 2014] \\
\hline Hypocalypteae & \\
\hline $\begin{array}{l}\text { Hypocalyptus coluteoides, Hypocalyptus oxalidifolius, } \\
\text { Hypocalyptus sophoroides }\end{array}$ & Burkholderia [Beukes et al. 2013] \\
\hline Indigofereae & \\
\hline Indigofera angustifolia & Burkholderia [Lemaire et al. 2015] \\
\hline Indigofera astragalina & Bradyrhizobium [Doignon-Bourcier et al. 1999] \\
\hline Indigofera hirsuta & Bradyrhizobium [Doignon-Bourcier et al. 1999] \\
\hline Indigofera senegalensis & Bradyrhizobium [Doignon-Bourcier et al. 1999] \\
\hline Indigofera tinctoria & Bradyrhizobium [Doignon-Bourcier et al. 1999] \\
\hline
\end{tabular}




\begin{tabular}{|c|c|}
\hline Loteae & \\
\hline Coronilla varia & $\begin{array}{l}\text { Mesorhizobium [Yang et al. 2013], Rhizobium [Tan } \\
\text { et al. 1999; Tan et al. 2001; Yang et al. 2013] }\end{array}$ \\
\hline Ornithopus compressus, Ornithopus sativus & Bradyrhizobium [Stepkowski et al. 2005] \\
\hline \multicolumn{2}{|l|}{ Podalyrieae } \\
\hline $\begin{array}{l}\text { Cyclopia buxifolia, Cyclopia genistoides, Cyclopia } \\
\text { glabra, Cyclopia intemedia, Cyclopia longifolia, Cyclopia } \\
\text { maculata, Cyclopia meyeriana, Cyclopia pubescens, } \\
\text { Cyclopia sessiflora, Cyclopia subternata }\end{array}$ & Burkholderia [Beukes et al. 2013] \\
\hline Podalyria burchelli & Burkholderia [Lemaire et al. 2015] \\
\hline Podalyria calyptrata & $\begin{array}{l}\text { Burkholderia [Beukes et al. 2013; Lemaire et al. 2015; } \\
\text { Lemaire et al. 2016] }\end{array}$ \\
\hline Podalyria sericea & Burkholderia [Lemaire et al. 2015] \\
\hline Virgilia divaricata & Rhizobium [Lemaire et al. 2015] \\
\hline Virgilia oroboides & Burkholderia [Beukes et al. 2013; Lemaire et al. 2015] \\
\hline \multicolumn{2}{|l|}{ Robineae } \\
\hline Gliricidia sepium & $\begin{array}{l}\text { Ensifer [Bala \& Giller, 2001], Rhizobium [Bala \& } \\
\text { Giller, 2001] }\end{array}$ \\
\hline Robinia pseudocacia & $\begin{array}{l}\text { Mesorhizobium [Ulrich \& Zaspel 2000; Mierzwa et } \\
\text { al. 2009], Rhizobium [Ulrich \& Zaspel 2000; Han et } \\
\text { al. 2008b] }\end{array}$ \\
\hline \multicolumn{2}{|l|}{ Sesbanieae } \\
\hline Sesbania aculeata & Ensifer [Lortet et al. 1996] \\
\hline Sesbania cannabina & $\begin{array}{l}\text { Ensifer [Lortet et al. 1996; Chen \& Lee, 2001; Wang } \\
\text { et al. 2013a; Li et al. 2016], Neorhizobium [Li et al. } \\
\text { 2016], Rhizobium [Chen \& Lee 2001; Li et al. 2016] }\end{array}$ \\
\hline Sesbania exasperata & Rhizobium [Vinuesa et al. 2005b] \\
\hline Sesbania grandiflora & Ensifer [Lortet et al. 1996] \\
\hline Sesbania herbacea & Rhizobium [Wang et al. 1998] \\
\hline Sesbania pachycarpa & Ensifer [Lortet et al. 1996] \\
\hline Sesbania punicea & $\begin{array}{l}\text { Azorhizobium [Blanco et al. 2008; Lemaire et al. } \\
\text { 2015], Mesorhizobium [Vinuesa et al. 2005b], } \\
\text { Rhizobium [Blanco et al. 2008] }\end{array}$ \\
\hline Sesbania rostrata & $\begin{array}{l}\text { Azorhizobium [Dreyfus et al. 1988; Moreira et al. } \\
\text { 2006], Bradyrhizobium [Sinsuwongwat et al. 2002], } \\
\text { Ensifer [Lortet et al. 1996; Ogasawara et al. 2003], } \\
\text { Rhizobium [Sinsuwongwat et al. 2002] }\end{array}$ \\
\hline Sesbania sericea & $\begin{array}{l}\text { Mesorhizobium [Vinuesa et al. 2005b], Rhizobium } \\
\text { [Vinuesa et al. 2005b] }\end{array}$ \\
\hline Sesbania sesban & $\begin{array}{l}\text { Ensifer [Lortet et al. 1996; Bala \& Giller, 2001; } \\
\text { Degefu et al. 2012], Mesorhizobium [Bala \& Giller } \\
\text { 2001; Odee et al. 2002; Degefu et al. 2011], } \\
\text { Rhizobium [Bala \& Giller 2001; Odee et al. 2002] }\end{array}$ \\
\hline Sesbania virgata & $\begin{array}{l}\text { Azorhizobium [Moreira et al. 2006], Rhizobium } \\
\text { [Blanco et al. 2008] }\end{array}$ \\
\hline Sesbania sp. & Ensifer [Lortet et al. 1996] \\
\hline \multicolumn{2}{|l|}{ Sophoreae } \\
\hline Sophora alopecuroides & $\begin{array}{l}\text { Ensifer [Zhao et al. 2010] Mesorhizobium [Zhao et al. } \\
\text { 2010], Phyllobacterium [Zhao et al. 2010], Rhizobium } \\
\text { [Han et al. 2008b; Zhao et al. 2010] }\end{array}$ \\
\hline Sophora flavescens & $\begin{array}{l}\text { Bradyrhizobium [Jiao et al. 2015a], Ensifer [Jiao et al. } \\
\text { 2015a], Mesorhizobium [Jiao et al. 2015a], } \\
\text { Phyllobacterium [Jiao et al 2015b], Rhizobium [Jiao et }\end{array}$ \\
\hline
\end{tabular}




\begin{tabular}{|l|l|}
\hline & al. 2015a] \\
\hline $\begin{array}{l}\text { Sophora longicarinata, S. microphylla, S. prostrata, S. } \\
\text { tetraptera }\end{array}$ & Mesorhizobium [Tan et al. 2015] \\
\hline Sophora viciifolia & Mesorhizobium [Tan et al. 1999] \\
\hline Thermopsideae & \\
\hline $\begin{array}{l}\text { Ammopiptanthus nanus, Ammopiptanthus } \\
\text { mongolicus }\end{array}$ & $\begin{array}{l}\text { Ensifer [Zhao et al. 2016], Neorhizobium [Zhao et al. } \\
\text { 2016], Pararhizobium [Zhao et al. 2016], Rhizobium }\end{array}$ \\
\hline Anagyris latifolia & [Zhao et al. 2016] \\
\hline Thermopsis lupinoides & Mesorhizobium [Donate-Correa et al. 2007] \\
\hline
\end{tabular}

Table 4. Legume-rhizobia symbioses of species in the sub-family Papilionoideae with determinate nodules.

\begin{tabular}{|c|c|}
\hline $\begin{array}{l}\text { Papilionoideae } \\
\text { Tribes and genera }\end{array}$ & Rhizobia - field \\
\hline \multicolumn{2}{|l|}{ Dalbergieae } \\
\hline Adesmia bicolor & Rhizobium [Bianco et al. 2013] \\
\hline Aeschynomene afraspera & Bradyrhizobium [Miché et al. 2010] \\
\hline Aeschynomene americana & Bradyrhizobium [Miché et al. 2010; Noisangian et al. 2012] \\
\hline $\begin{array}{l}\text { Aeschynomene ciliata, Aeschynomene } \\
\text { elaphroxylon }\end{array}$ & Bradyrhizobium [Miché et al. 2010] \\
\hline Aeschynomene indica & Bradyrhizobium [Van Berkum \& Eardly, 2002; Miché et al. 2010] \\
\hline Aeschynomene rudis & Bradyrhizobium [Montecchia et al. 2002; Miché et al. 2010] \\
\hline $\begin{array}{l}\text { Aeschynomene scabra, } \\
\text { Aeschynomene sensitiva, } \\
\text { Aeschynomene shimperi }\end{array}$ & Bradyrhizobium [Miché et al. 2010] \\
\hline Arachis duranensis & Bradyrhizobium [Chen et al. 2014] \\
\hline Arachis hypogaea & $\begin{array}{l}\text { Bradyrhizobium [Urtz \& Elkan, 1996; Sinsuwongwat et al. 2002; Yang } \\
\text { et al. 2005; Taurian et al. 2006; El-Akhal et al. 2008; Steenkamp et al. } \\
\text { 2008; Chang et al. 2011; Munoz et al. 2011; Wang et al. 2013b; } \\
\text { Grönemeyer et al. 2014; Li et al. 2015; Chen et al. 2016], Rhizobium } \\
\text { [Taurian et al. 2006; El-Akhal et al. 2008] }\end{array}$ \\
\hline Centrolobium paraense & Bradyrhizobium [Baraúna et al. 2014; Zilli et al. 2014] \\
\hline $\begin{array}{l}\text { Dalbergia baroni, Dalbergia louveli, } \\
\text { Dalbergia madagascariensis, } \\
\text { Dalbergia maritima, Dalbergia } \\
\text { monticola, }\end{array}$ & Bradyrhizobium [Rasolomampianina et al. 2005] \\
\hline Dalbergia odorifera & Burkholderia [Lu et al. 2012] \\
\hline Dalbergia purpurascens & Bradyrhizobium [Rasolomampianina et al. 2005] \\
\hline Dalbergia sp. & Bradyrhizobium [Rasolomampianina et al. 2005] \\
\hline Pterocarpus officinalis & Bradyrhizobium [Le Roux et al. 2014] \\
\hline Pterocarpus indicus & Bradyrhizobium [Sinsuwongwat et al. 2002; Manassila et al. 2007] \\
\hline Zornia glochidiata & Bradyrhizobium [Gueye et al. 2009] \\
\hline \multicolumn{2}{|l|}{ Desmodieae } \\
\hline Desmodium caudatum & Bradyrhizobium [Gu et al. 2007] \\
\hline Desmodium elegans & $\begin{array}{l}\text { Bradyrhizobium [Gu et al. 2007; Xu et al. 2016], Pararhizobium [Xu et al. } \\
\text { 2016] }\end{array}$ \\
\hline
\end{tabular}




\begin{tabular}{|c|c|}
\hline Desmodium fallax & Bradyrhizobium [Gu et al. 2007] \\
\hline Desmodium gangeticum & Bradyrhizobium [Gu et al. 2007; Xu et al. 2016] \\
\hline Desmodium heterocarpan & Bradyrhizobium [Gu et al. 2007; Delamuta et al. 2015] \\
\hline Desmodium microphyllum & $\begin{array}{l}\text { Bradyrhizobium [Gu et al. 2007], Mesorhizobium [Gu et al. 2007], } \\
\text { Rhizobium [Gu et al. 2007] }\end{array}$ \\
\hline Desmodium oldhami & Rhizobium [Xu et al. 2016] \\
\hline Desmodium racemosum & $\begin{array}{l}\text { Bradyrhizobium [Gu et al. 2007], Ensifer [Gu et al. 2007], Rhizobium [Gu } \\
\text { et al. 2007] }\end{array}$ \\
\hline Desmodium sequax & $\begin{array}{l}\text { Bradyrhizobium [Gu et al. 2007], Ensifer [Gu et al. 2007], Mesorhizobium } \\
\text { [Xu et al. 2016], Pararhizobium [Xu et al. 2016], Rhizobium [Gu et al. } \\
\text { 2007; Xu et al. 2016] }\end{array}$ \\
\hline Desmodium sinuatum & Rhizobium [Chen et al. 1997] \\
\hline Desmodium triflorum & Bradyrhizobium [Gu et al. 2007] \\
\hline Kummerowia stipulacea & $\begin{array}{l}\text { Bradyrhizobium [Lin et al. 2007; Wang et al. 2009], Rhizobium [Lin et al. } \\
\text { 2007] }\end{array}$ \\
\hline Kummerowia striata & $\begin{array}{l}\text { Bradyrhizobium [Lin et al. 2007], Ensifer [Lin et al. 2007], Rhizobium } \\
\text { [Lin et al. 2007] }\end{array}$ \\
\hline Lespedeza bicolor & $\begin{array}{l}\text { Bradyrhizobium [Yao et al. 2002], Ensifer [Yao et al. 2002], } \\
\text { Mesorhizobium [Wang et al. 2009] Rhizobium [Yao et al. 2002] }\end{array}$ \\
\hline $\begin{array}{l}\text { Lespedeza capitata, Lespedeza } \\
\text { cuneata }\end{array}$ & Bradyrhizobium [Yao et al. 2002] \\
\hline Lespedeza cystobotrya & Ensifer [Yao et al. 2002], Rhizobium [Wei et al. 2008b] \\
\hline Lespedeza daurica & $\begin{array}{l}\text { Bradyrhizobium [Yao et al. 2002], Ensifer [Yao et al. 2002], } \\
\text { Mesorhizobium [Yao et al. 2002] }\end{array}$ \\
\hline Lespedeza davidii & Rhizobium [Wei et al. 2008b] \\
\hline Lespedeza inschanica & Ensifer [Yao et al. 2002] \\
\hline $\begin{array}{l}\text { Lespedeza juncea, Lespedeza } \\
\text { procumbens, Lespedeza stipulacea, } \\
\text { Lespedeza striata }\end{array}$ & Bradyrhizobium [Yao et al. 2002] \\
\hline Lespedeza tomentosa & Ensifer [Yao et al. 2002] \\
\hline \multicolumn{2}{|l|}{ Phaseoleae } \\
\hline $\begin{array}{l}\text { Amphicarpaea bracteata, } \\
\text { Amphicarpaea edgeworthii }\end{array}$ & Bradyrhizobium [Parker et al. 2004] \\
\hline Amphicarpaea trisperma & Rhizobium [Tan et al. 1999] \\
\hline Bolusafra bituminosa & Burkholderia [Lemaire et al. 2015] \\
\hline Cajanus cajan & Bradyrhizobium [Araujo et al. 2015] \\
\hline Canavalia rosea & Ensifer [Chen et al. 2000] \\
\hline Centrosema pascuorum & Bradyrhizobium [Sinsuwongwat et al. 2002] \\
\hline Centrosema pubescens & Bradyrhizobium [Hélene et al. 2015] \\
\hline Dipogon lignosus & Burkholderia [Liu et al. 2014] \\
\hline Glycine max & $\begin{array}{l}\text { Bradyrhizobium [Xu et al. 1995; Sinsuwongwat et al. 2002; Barcellos et } \\
\text { al. 2007; Appunu et al. 2009; Wang et al. 2009; Zhang et al. 2011; } \\
\text { Jaiswal et al. 2012; Tang et al. 2012; Wang et al. 2013c; Ribeiro et al. } \\
\text { 2015], Ensifer [Peng et al. 2002; Barcellos et al. 2007; Appunu et al. } \\
\text { 2009; Li et al. 2011; Zhang et al. 2011], Rhizobium [Alam et al. 2015] }\end{array}$ \\
\hline Glycine soja & Bradyrhizobium [Wang et al. 2009; Wu et al. 2011], Ensifer [Wu et al. \\
\hline
\end{tabular}




\begin{tabular}{|c|c|}
\hline & 2011], Rhizobium [Zhao et al. 2014] \\
\hline Lablab purpureus & $\begin{array}{l}\text { Bradyrhizobium [Chang et al. 2011; Wang et al. 2013b; Grönemeyer et } \\
\text { al. 2014] }\end{array}$ \\
\hline Neonotonia wightii & Bradyrhizobium [Delamuta et al. 2015] \\
\hline Pachyrhizus erosus & $\begin{array}{l}\text { Bradyrhizobium [Fuentes et al. 2002; Rodriguez-Navarro et al. 2004; } \\
\text { Ramirez-Bahena et al. 2009], Rhizobium [Fuentes et al. 2002] }\end{array}$ \\
\hline Pachyrhizus ferrugineus & Bradyrhizobium [Rodriguez-Navarro et al. 2004] \\
\hline Pachyrhizus tuberosus & Bradyrhizobium [Rodriguez-Navarro et al. 2004] \\
\hline Phaseolus lunatus & $\begin{array}{l}\text { Bradyrhizobium [López-López et al. 2013; Durán et al. 2014; } \\
\text { Matsubara \& Zúñiga-Dávila 2015], Rhizobium [Matsubara \& } \\
\text { Zúñiga-Dávila 2015] }\end{array}$ \\
\hline Phaseolus vulgaris & $\begin{array}{l}\text { Bradyrhizobium [López-López et al. 2013; Wang et al. 2016], } \\
\text { Burkholderia [Talbi et al. 2010; Dall'Agnol et al. 2016], Ensifer } \\
\text { [Mhamdi et al. 2002; Mnasri et al. 2007; Mnasri et al. 2012; Wang et } \\
\text { al. 2016], Pararhizobium [Wang et al. 2016], Rhizobium } \\
\text { [Martinez-Romero et al. 1991; Amarger et al. 1997; Mhamdi et al. } \\
\text { 2002; Mostasso et al. 2002; Valverde et al. 2006; Mnasri et al. 2007; } \\
\text { Wang et al. 2009; Wang et al. 2011; López-López et al. 2012; Mnasri et } \\
\text { al. 2012; Ribeiro et al. 2013; Zahran et al. 2013; Cao et al. 2014; } \\
\text { Grönemeyer et al. 2014; Wang et al. 2016] }\end{array}$ \\
\hline Pueraria phaseoloides & Bradyrhizobium [Sarr et al. 2016] \\
\hline Rhynchosia aurea & Ensifer [Gehlot et al. 2012] \\
\hline Rhynchosia ferulifolia & Burkholderia [Garau et al. 2009; De Meyer et al. 2013] \\
\hline Rhynchosia minima & Bradyrhizobium [Doignon-Bourcier et al. 1999; Garau et al. 2009] \\
\hline Rhynchosia totta & Bradyrhizobium [Garau et al. 2009] \\
\hline Vigna angularis & $\begin{array}{l}\text { Bradyrhizobium [Han et al. 2009], Ensifer [Han et al. 2009], Rhizobium } \\
\text { [Han et al. 2009] }\end{array}$ \\
\hline Vigna radiata & $\begin{array}{l}\text { Bradyrhizobium [Zhang et al. 2008; Risal et al. 2012], Ensifer [Zhang et } \\
\text { al. 2008], Rhizobium [Zhang et al. 2008] }\end{array}$ \\
\hline Vigna sinensis & Bradyrhizobium [Sinsuwongwat et al. 2002] \\
\hline Vigna subterranea & $\begin{array}{l}\text { Bradyrhizobium [Grönemeyer et al. 2014; Onyango et al. 2015], } \\
\text { Burkholderia [Onyango et al. 2015], Rhizobium [Onyango et al. 2015] }\end{array}$ \\
\hline Vigna ungiuculata & $\begin{array}{l}\text { Achromobacter [Guimarães et al. 2012], Bradyrhizobium [Steenkamp et } \\
\text { al. 2008; Zhang et al. 2008; Guimarães et al. 2012; Bejarano et al. 2014; } \\
\text { Grönemeyer et al. 2014; Silva et al. 2014], Burkholderia [Guimarães et } \\
\text { al. 2012], Rhizobium [Zhang et al. 2008; Guimarães et al. 2012] }\end{array}$ \\
\hline \multicolumn{2}{|l|}{ Psoraleae } \\
\hline $\begin{array}{l}\text { Otholobium bracteolatum, } \\
\text { Otholobium hirtum, Otholobium } \\
\text { virgatum, Otholobium zeyhari, } \\
\text { Otholobium sp }\end{array}$ & Mesorhizobium [Lemaire et al. 2015] \\
\hline Psoralea asarina & Burkholderia [Kanu \& Dakora, 2012] \\
\hline Psoralea corylifolia & Ensifer [Wang et al. 2013a] \\
\hline Psoralea pinnata & $\begin{array}{l}\text { Burkholderia [Kanu \& Dakora, 2012], Mesorhizobium [Kanu \& Dakora, } \\
\text { 2012; Lemaire et al. 2015] }\end{array}$ \\
\hline \multicolumn{2}{|l|}{ Loteae } \\
\hline Lotus arabicus, Lotus arinagensis & Ensifer [Merabet et al. 2010] \\
\hline $\begin{array}{l}\text { Lotus bertheloti, Lotus callis-viridis, } \\
\text { Lotus campylocladus }\end{array}$ & Mesorhizobium [Lorite et al. 2010a] \\
\hline Lotus corniculatus & $\begin{array}{l}\text { Geobacillus [Ampomah \& Huss-Danell, 2011], Mesorhizobium [Jarvis } \\
\text { et al. 1997; Lorite et al. 2010a; Lorite et al. 2010b; Ampomah \& } \\
\text { Huss-Danell, 2011; Marcos-Garcia et al. 2015], Paenibacillus }\end{array}$ \\
\hline
\end{tabular}




\begin{tabular}{|l|l|}
\hline & $\begin{array}{l}\text { [Ampomah \& Huss-Danell, 2011], Rhodococcus [Ampomah \& } \\
\text { Huss-Danell, 2011] }\end{array}$ \\
\hline Lotus creticus & $\begin{array}{l}\text { Ensifer [Merabet et al. 2010; Rejili et al. 2012], Mesorhizobium } \text { [Merabet } \\
\text { et al. 2010; Rejili et al. 2012], Rhizobium [Merabet et al. 2010; Rejili et } \\
\text { al. 2012], }\end{array}$ \\
\hline Lotus frondosus & Mesorhizobium [Han et al. 2008a], Rhizobium [Han et al. 2008b] \\
\hline Lotus halophyllus & Ensifer [Rejili et al. 2012] \\
\hline $\begin{array}{l}\text { Lotus kunkeli, Lotus lancerottensis, } \\
\text { Lotus maculatus }\end{array}$ & Ensifer [Léon-Barrios et al. 2009] \\
\hline Lotus pyranthus & Mesorhizobium [Lorite et al. 2010a] \\
\hline Lotus sessilifolius & Ensifer [Léon-Barrios et al. 2009], Mesorhizobium [Lorite et al. 2010a] \\
\hline Lotus tenuis & $\begin{array}{l}\text { Mesorhizobium [Estrella et al. 2009; Lorite et al. 2010b; Sannazzaro et } \\
\text { al. 2011], Rhizobium } \text { [Han et al. 2008b; Estrella et al. 2009] }\end{array}$ \\
\hline Lotus uliginosus & Bradyrhizobium [Lorite et al. 2012] \\
\hline
\end{tabular}

(C) 2016 by the authors; licensee Preprints, Basel, Switzerland. This article is an open access article distributed under the terms and conditions of the Creative Commons by Attribution (CC-BY) license (http://creativecommons.org/licenses/by/4.0/). 